\title{
Democracy and Foreign Education ${ }^{1}$
}

November 2006

\author{
Antonio Spilimbergo \\ Research Department, IMF; CEPR; WDI
}

\begin{abstract}
Despite the large amount of private and public resources spent on foreign education, there is no systematic evidence that foreign educated individuals foster democracy in their home countries. Using a unique panel dataset on foreign students starting from 1950, I show that foreigneducated individuals promote democracy in their home country, but only if the foreign education is acquired in democratic countries. Instrumental variables exclude reverse causality and/or omitted variables. The results are robust to several estimation techniques and to the inclusion of a variety of control variables, including democracy in trading partners, neighboring countries, level of income, and level and stock of education.
\end{abstract}

JEL Classification Numbers: D72, D74, H11

Keywords: education, democracy, development, institutions, international students Authors' E-mail address: aspilimbergo@imf.org

\footnotetext{
${ }^{1}$ The views expressed in this paper are those of the author and do not necessarily represent those of the IMF, its Board of Directors. I thank my colleagues at the IMF for useful discussions and the participants to the 2006 NBER summer institute group on national security; I am particularly indebted to Daron Acemoglu, Olivier Blanchard, Charles Clotfelter, Steven Davis, Martin Feldstein, Simon Johnson, Kala Krishna, Larry Katz, James Rauch, Andy Rose, Mark Rosenzweig, and Arvind Subramanian for useful suggestions, and Pierre Yared and Ben Jones for sharing their data. José Romero provided excellent research assistantship.
} 


\section{INTRODUCTION}

Do foreign educated individuals play an important role in fostering democracy in their home country? Despite the large amount of resources spent on financing foreign education there is no systematic study on the effects of foreign education on democracy. This paper fills this gap using a large data set of foreign students, which includes almost all receiving and sending countries and spans for over 50 years.

Numerous policy initiatives and large investment in the US and elsewhere are based on the notion that foreign-educated students promote democracy in their own origin country. Through the Fulbright Program, the US government has financed more than 158,000 foreigners studying in the US. ${ }^{2}$ With an endowment of over $\$ 12$ billion, the Ford Foundation has similarly pursued the goal of "strengthening democratic values, reducing poverty and injustice, promoting international cooperation, and advancing human achievement," since $1936{ }^{3}$

The idea that foreign education is an important instrument of foreign policy has received new attention recently as the US president has repeatedly stated that foreign education is a pillar of his strategy in the "war on terror." “...\$474 million [are allocated] for Educational and Cultural Exchange programs, an increase of approximately $\$ 48$ million over the 2006 level, with an emphasis on the Muslim world. These programs seek to improve the world's understanding of the United States and Americans' understanding of the world ..."4

\footnotetext{
2 “The Fulbright Program supports educational exchanges that strengthen understanding and communication between the United States and over 140 countries. It is an effective and prestigious form of public diplomacy." "Many Fulbrighters are young professionals who will return to responsible positions in their home countries. They often are involved in building institutions and government service when they return bome." From the Fulbright program website (http://exchanges.state.gov/education/fulbright/). Italics added by the author.

${ }^{3}$ From the Ford foundation website (http://www.fordfound.org/).

${ }^{4}$ Excerpts from the document "Winning the War on Terror and Spreading Freedom" outlining budget priorities, White House's website (http://www.whitehouse.gov/OMB/pdf/Diplomacy-07.pdf).
} 
The US government not only actively finances the education of foreign students in the US but also annually issues more than 250,000 nonimmigrant visas for foreign students (F1 Visa), one of the main ways of entering the country; more than 5 million individuals have received visas to study in the US since 1971. ${ }^{5}$ The US efforts to educate foreign students (and future leaders) have produced impressive results; 46 current and 165 former heads of governments are products of American higher education. Well-known foreign leaders who studied in the US include among many others: Benazir Bhutto (Pakistan), Carlos Salinas de Gortari, Vicente Fox (Mexico), Ehud Barak (Israel), Corazon Aquino (Philippines), Hamid Karzai (Afghanistan), and Michelle Bachelet (Chile). ${ }^{6}$

Prominent scholars argue that foreign education has played a fundamental role in the collapse of the Soviet Union (Richmond, 2003). Student exchange between the US and Soviet Union took off after the signing of the so-called Lacy-Zarubin agreement on cultural exchange; the US signed the agreement with the goal of "eroding the Soviet social system" according to the Soviet historian Arbatov. Richmond (2003) quotes the sociologist Kasoff: "Historians dealing with the collapse of Communism will want to devote more than one chapter to the extraordinary impact of East-West scholarly exchanges... ...seeds of change that would blossom into the democratic revolutions of 1989-90 were being sown by scholars from east and West.” For instance, Alexander Yakovlev, the intellectual architect of perestroika, was one of the four Soviet graduate students enrolled at Columbia University in fall 1958.

In addition to the US, a number of Western countries fund foreign students. For instance, the German Academic Exchange Service (or DAAD), which was founded in 1925, “currently awards more than 65,000 fellowships a year and is the largest grantor of international academic mobility support in the world." Its goals include "to enable young academic elites from around

\footnotetext{
${ }^{5}$ INS estimates that in any given day in 2004 more than 600,000 foreign students were present in the US (from the INS website http://www.uscis.gov/graphics/shared/statistics/publications/NIM 2004.pdf.) Note that the VISA count underestimates the number of foreigners, given that over 60,000 Canadian students do not require a F1 visa to study in the US.

${ }^{6}$ From the website of the "American Immigration Law Foundation" (http://www.ailf.org/).
} 
the world to become leaders in the fields of science, culture, economics, and politics - as well as friends and partners of Germany" and "to support the process of economic and democratic reform in developing countries and in the transition countries of Middle and Eastern Europe by supporting their academic research and progress."”

Besides Western countries, many governments have actively financed foreign education in the hope of molding future ruling classes and spreading specific ideas. Socialist countries had an active policy to attract and indoctrinate future leaders (Bollag, 1990); the Moscow-based People's Friendship University (formerly known as Patrice Lumumba University) was founded in 1960 with the explicit mandate to prepare future socialist leaders in Africa, Asia, and Latin America. South African president Mbeki considers foreign students from other African countries as a primary way to spread his vision of “African Renaissance” (Malan, 2001). Finally, several Arab scholars see Islamic education as a way to form future leaders in Islamic countries.

The large amount of resources invested in foreign education and the anecdotic evidence on the foreign educated leaders suggest that indeed foreign education plays an important role in many aspects of the economic and political life of the sending countries. While there are many issues involved in foreign education, this paper focuses only on the question of whether foreign education is associated with the spreading of democracy in sending countries.

This paper also contributes to the literature of the role of leaders on the economic and political outcomes of countries. Foreign educated individuals are at best a small minority of the population - in recent years, foreign students have been between 2 and 3 individuals per million of native population on average (see Figure1). Nevertheless, they are over-represented among

\footnotetext{
${ }^{7}$ From the DAAD website (Deutscher Akademischer Austauch Dienst, German Academic Exchange Service); http://www.daad.de/en/index.html. Among world leaders who have been benefited from DAAD funds are: Mahmoud Hamdi Zakzouk (minister of religion, Egypt), Amin Farhang (minister for reconstruction, Afghanistan), Luc Ferry (minister of education, France), Vassilios Skuris (president of the Court of Justice of the European Communities), Andrei Marga (minister of education, Romania), Leoluca Orlando (mayor of Palermo, Italy), Wladyslaw Bartoszewski (foreign minister, Poland), and Wangari Maathai (deputy-secretary for environment, Kenya).
} 
leaders (see table 11). In a related research, Jones and Olken (2005) show that even individual leaders matter for economic growth. The present paper represents a contribution to this literature because it investigates the role of a very restricted but influential minority in changing political regimes.

The rest of the paper is organized as follows. Section II provides an overview of the literature, with a focus on the current debate on the relationship between democracy and education. Section III presents stylized facts on foreign education and democracy. Section IV provides econometric evidence on the relationship between education and democracy. Section V explores the determinant of the choice of destination countries for foreign students, derives some valid instruments, and analyzes the issue of reverse causality. Section VI deals with the issue of omitted variables, which could explain the correlation between democracy and foreign education. Section VII presents several additional robustness tests, including heterogeneity of the sample. Section VIII discusses stay rates and present complementary evidence on the role of foreign students on democracy. Section IX discusses the results and concludes.

\section{LITERATURE REVIEW}

The relationship between education and democracy has been studied for a long time. At least since Lipset (1959) political scientists have speculated that education leads to more democratic regimes. Starting with Barro (1999), economists have found a strong empirical correlation between levels of education and democracy. While nobody disputes the strong positive correlation between democracy and education, there has been disagreement on the methodology to control for other factors that may influence both education and democracy and, consequently, on the interpretation of this correlation.

Glaeser, Ponzetto, and Schleifer (2006) claim that there is a good deal of empirical support showing that higher level of education attainment leads to more democratic politics. ${ }^{8}$ According

8 See also Glaeser, La Porta, Lopes-de-Silanes, and Shleifer (2004), and Papaioannou and Siourounis (2005). 
to Glaeser et al. (2006), the real question is to understand the specific mechanisms that explain the causal link from education to democracy. They argue that schooling teaches people to interact with others; therefore, education, by lowering the cost of interaction and political engagement, enlarges the constituency for democracy. For the present paper, which focuses on foreign education, two aspects of this point of view are important. First, for Glaeser et al. (2006) the content of education (e.g. democratic values, technical knowledge, or political indoctrination) matters less than the socializing experience of studying together and learning how to interact. Second, average education and not the elites' level of education is what matters.'

On the contrary, Acemoglu, Johnson, Robinson, and Yared (2005a) claims that the strong crosssectional correlation between democracy and education is due to omitted factors more than to a causal relationship. In a companion paper, Acemoglu et al. (2005b) argues that long-term parallel evolution of democracy and education may be explained by institutional developments, including settlers' mortality in the colonies, density of indigenous population and early experiences with democracy. Besides their respective conclusions, these papers make some important methodological points that are relevant for this paper. First, they show that the correlation between level of democracy and (lagged) level of education attainment is not enough to claim causation if underlying third variables are not properly controlled for. Second, they point out that a panel regression of democracy on education should always contain time variables to control for common trend that causes spurious correlations. Finally, they reveal that long-run difference regressions may also be appropriate to explore causation.

Despite their different conclusions, both Glaeser et al. (2006) and Acemoglu et al. (2005a) share some common features that this paper improve upon. First, both studies assume that the quality of education is the same in all countries (so educational attainment or enrollment are sufficient statistics for the level of education). However, the quality of education, especially at tertiary level,

${ }^{9}$ Castelló-Climent (2006) finds evidence that an increase in the average years of schooling of the majority of population matters more for democracy than the average yours of schooling of total population. This reinforces the view that the education level of the median voter is more relevant for democracy than the generic level of education. Milligan, Moretti, and Oreopoulos, and Dee (2004) also find evidence that education increases participation in election and support for free speech. 
is heterogeneous across countries, creating a problem of error in variables (Hanushek and Kimko, 2000). Second, even leaving education quality aside, another source of measurement error stems from the fact that the primary sources for international data on education are national agencies. These agencies are not all equally reliable and may have bias in providing education data. Third, the data on educational attainment supply the average years of education and provide no information on the distribution of education; therefore, we do not know if a restricted group of highly educated individuals is more influential than a large mass of moderately educated individuals.

Data on foreign students can solve these issues and clarifying the relationship between education and democracy. First, the quality of tertiary education, especially in universities where foreign students go, is presumably more homogeneous than tertiary education at home. Second, data on international students are collected by host universities and countries, which often require visa to admit foreign students; this leads to better quality data. In addition, host countries do not have any incentive to misreport data from any particular country. Finally, the data on international students is for tertiary education, a relatively homogenous group.

The debate between these two views on the link between education and democracy is also severely limited by the fact that it is very difficult to find a good set of instruments for domestic education, which satisfies the exclusion criterion (i.e. factors which influence democracy only through education). In the absence of a credible instrumental strategy, the debate has relied on indirect evidence. Investigating the relationship through the window of foreign education (in contrast to domestic education), it becomes possible to use an entire range of credible instruments, which depend on the receptivity of foreign students in recipient countries. This is an important contribution of this paper to the general debate of education and democracy, which goes beyond the role of foreign education.

In addition to the literature on democracy and education, there is also a growing interest in foreign education per se. The US being the largest recipient country of foreign students, most studies focus on the US (for a recent review, see Aslambeigui and Montecinos, 1998); this paper expands on this research by looking at a large number of countries. 
The increasing number of foreign students has also its critics. Borjas (2002) argues that the foreign student VISA program is "littered with corruption and fraud" and that the economic "benefits from the program are greatly exaggerated, and the program may well generate a net economic loss for the country." Although the present paper does not deal with these issues directly, it presents evidence that there are some clear benefits from foreign education in terms of increasing the spreading of democracy.

\section{STYLIZED FACTS ON FOREIGN EDUCATION AND DEMOCRACY}

Democracy is a difficult concept to define and several indices have been proposed to measure it. For the purpose of this study, I consider three indices currently used: the Freedom House Index, the polity II index, and the index proposed by Przeworski, Alvarez, Cheibub, and Limongi (1990). For the sake of space, the advantages and the limits of various indices or the vast literature which use them are not discussed here. ${ }^{10}$ The only point that is important to make here is that the trend toward more democratic regimes has not been linear. Significant retrenchment of democracy has not only been observed in isolated countries but also in several regions of the world. The examples include the general decrease in democracy in Asia in the 1950s and 1960s, the marked decline in Latin America in 1960s and 1970s, and the prolonged stasis in Africa since the 1960s (Acemoglu and Robinson, 2005). These unequal marches toward democracy beg the question: which factors explain the different paths?

In order to investigate the influence of foreign education in harboring democracy, I use the foreign education database by UNESCO, which is the most complete for international education. ${ }^{11}$ This database reports the bilateral students' flows at the tertiary level from 1950 to

\footnotetext{
10 The data appendix describes them in more details. For an exhaustive discussion of these indices, see Przeworski, Alvarez, Cheibub, and Limongi (2000) or Acemoglu and Robinson (2005).

11 The UNESCO database has been used before only as a cross-section or as a panel with two crosssections but not for the entire period which starts in the 1950s. Part of the problem is that the database is available only in hard copy except for the last few years. The other reason is that the database requires a considerable amount of preparatory work to clear it from evident mistakes (see data appendix for description). Note also that there are occasional discrepancies with the data for the US provided by Open Doors.
} 
2003. Some industrialized countries are covered from 1950 and almost all countries are represented as sending or receiving starting in 1960. The data are gathered from host countries' authorities, which, in turn, get the primary data from local universities and/or immigration databases.

The total number of foreign students has increased substantially in the last 50 years from about 50,000 to more than 2 million in 2002. The number of students abroad has grown more than the population, though it has declined slightly as share of enrollment in tertiary education (figure 1).

The steady increase in the aggregate data masks some noticeable heterogeneity in the origin and host countries (Figure 2). The US has traditionally been the main host country with a share of approximately 30 percent. Second tier destination countries include France, Germany, and UK, each with a share of about 10 percent; in the last twenty years, there was a marked increase in the shares of Germany and UK accompanied by a relative decline of France's share. The share of students going to predominantly Muslim countries, which was over 10 percent in 1970, has steadily declined in the last thirty years. Finally, the countries belonging to the former Soviet bloc commanded a share of almost 10 percent between 1970 and 1990, but it has disappeared since the fall of Soviet Union. These changes in the composition of host countries need to be investigated carefully.

Not all foreign education is the same with respect to democracy. Students who were educated at Patrice Lumumba University or who got religious education in Pakistan brought very different concepts of democracy to their home country than students educated in US or UK. This suggests that any analysis must control for the quality of the institutions in host countries. Even when acquired in democratic countries foreign education sometimes may lead to the rejection of modern values of the host country. For instance, Sayyid Qutb, the spiritual leader of the Islamic fundamentalism, who studied between 1948 and 1950 in the Colorado State Collage of Education on a scholarship to study educational systems, concluded that major aspects of American life were "primitive" and shocking, including the mixing of the sexes, the enthusiasm 
for sports, and the love for Jazz. He, in particular, argued that Western freedom and democracy were manifestation of 'Jahiliyya' (ignorance of divine guidance). ${ }^{12}$ Foreign education may provide the opportunities for these dramatic contacts. Even if these single cases are tragically important for some countries, they are more exceptions than the rule. In absence of systematic information on the ideas that students absorb in foreign universities, this paper treats education acquired in democratic countries as democratic.

In order to capture this heterogeneity, I construct an index of average democracy in host countries, which is defined as the weighted average of democracy indices in host countries where a country's weight is the share of students going to that country over all foreign students from the origin country (see data appendix for formula and details). By construction, this index lies between 0 and 1 ; the index is 1 if all students abroad are in democratic countries and 0 if all students abroad are in dictatorial regimes.

On average, the level of democracy in host countries is much higher than in home countries, a sign that on average democratic countries attract more students (table 9). Trade seems more concentrated in relatively more democratic partners than in host countries (compare average democracy in trading partner and in students' host countries in table 9).

The source countries show considerable heterogeneity. The top panels of figures 3 to 6 show the total number of foreign students for a selected number of countries from different continents and very different experiences with democracy. The number of foreign students is quite different from country to country. For instance, the number of Chilean foreign students only recently surpassed 6,000 while Iranian students abroad reached almost 80,000 at their peak in 1978 but it was below 18,000 in 2000 .

12 Armstrong (2000) argues that religious fundamentalisms are the consequence of dramatic contacts between modernity and traditional society. Other examples include Saloth Sar, better known as Pol Pot, the Communist dictator of Cambodia, who studied engineering in France between 1949 and 1952. Gregory H. Stanton wrote that "key officials of Pol Pot's regime had read André Gunder Frank's Marxist theory that cities are parasitic on the countryside" and this provided the theoretical basis for the genocide. 
However, the total number of students abroad from one country masks intriguing composition effects. The bottom panels of figures 3 to 6 show the index of democracy at home and in host countries for Chile, Argentina, Iran, and Korea. These countries have very different profiles with respect to democracy. Chile started as a very democratic country until the coup d'état in 1973; after that, democracy was gradually restored in the late 1980s. It is interesting that the average democracy in foreign countries seems to anticipate domestic democracy. Chilean students tended to go to relatively undemocratic countries in the late 1960s, a possible sign of a polarized society at home. Immediately after the coup d'état, there was a large surge in foreign students, especially to democratic countries, an indication that many students were unhappy with the new regime and preferred to study abroad, especially in democratic countries. After that, the total number of students abroad remained constant until 2000 after which the composition shifted even more toward democratic countries. In the early 80s, five years before the change of regime at home, Chilean students started going to more democratic countries. A similar pattern happened in Argentina and Korea; in both cases, the change in the composition of student destination toward more democratic regimes clearly anticipated the introduction of democracy at home while the total number of students does not seem to anticipate the domestic change.

Finally, the average democracy in host countries of students from Iran seems to accompany (and slightly anticipate) the downward trend in democracy at home. It is peculiar that, despite major changes in the number of Iranian students abroad, the downward trend of democracy in host countries has remained unaltered in the last 50 years.

The four countries discussed above strongly suggest that the number of foreign students and especially the level of democracy in host countries predict future changes in the level of democracy at home. In order to study this correlation more systematically the following section presents econometric evidence from all countries.

\section{EMPIRICAL ANALYSIS}

In order to study the correlation between democracy and foreign education, I use mainly dynamic panel regressions. As in previous studies on democracy and education, including Barro (1999), Acemoglu et al. (2005a), and Glaeser et al. (2006), my main specification features level of 
democracy as the dependent variable. The explanatory variables are: past level of democracy, number of students abroad as a share of total population in the sending country, average level of democracy in the host countries, and the interaction between the two latter terms. ${ }^{13}$ All explanatory variables are lagged five years. ${ }^{14}$ In addition, all regressions have time and country fixed effects except when otherwise specified. The sources of the data are explained in the data appendix. The normalized number of students lagged five years is meant to capture the effect of foreign education. Following the discussion in the previous section, I use the average index of democracy in host countries as a control to capture the type of democracy that foreign students are exposed to. Finally, the interaction term measures if the marginal effect of foreign students depends on the level of democracy in host countries. This specification, while parsimonious, allows for the investigation of the different channels through which foreign education may have an impact on democracy. ${ }^{15}$ The basic specification is as follows:

$$
\begin{aligned}
d_{i t} & =\alpha d_{i t-5}+\beta \text { students abroad }_{i t-5}+\gamma \text { index of democracy in receiving countries } \text { cot }_{i t-5} \\
& +\delta\left(\text { students abroad }_{i t-5} * \text { index of democracy in receiving countries }_{i t-5}\right) \\
& + \text { country fixed effects }_{i}+\text { time fixed effects }_{t}+\varepsilon_{i t}
\end{aligned}
$$

Where $d_{i t}$ is the index of democracy in time $t$ in country $i$. The same specification is estimated for three different indices of democracy: the Freedom House's Political Rights Index, the composite polity index from the Polity IV dataset, and democracy index proposed by Przeworski, Alvarez, Cheibub, and Limongi (1990).

\footnotetext{
13 In principle, the number of students should be normalized using the number of 'potential foreign students,' i.e. the number of people in the relevant cohort or with a secondary education or tertiary education. However, using these data would limit the sample considerably.

${ }^{14}$ I choose the 5-year interval to follow the previous literature on education and democracy. However, I also tried a 10-year interval. While the number of observation sample in the sample is halved, the results discussed below are all confirmed; interestingly, the coefficients on democracy in host countries are usually larger in magnitude.

${ }^{15}$ I try different specifications in the robustness section.
} 
I use three different estimation techniques: pooled OLS, fixed effects OLS, and system GMM. The pooled OLS provide a first idea of how the data are correlated without controlling for country fixed effects and, therefore, overestimates the coefficient on the lag dependent variable. The fixed effects estimator controls for country effects but biases the coefficients on the lagged dependent variable downward. The GMM estimators provide consistent and unbiased estimates but depend on the particular set of instruments used; in this particular case, with very persistent dependent variables (democracy is constant for long period), system GMM should be used (Blundell and Bond, 1998; Bond, 2002). ${ }^{16}$

The first three columns of table 1a present the results for the Freedom House's index of political freedom using the techniques described above. As expected, democracy is very persistent; the coefficient on past democracy ranges between 847 in pooled OLS, which usually has upward bias, and .442 for the fixed effects, which usually displays downward bias. The unbiased GMM estimator of .541 is within this range. The coefficients on student abroad are insignificant in all the specifications. Democracy in host countries is always positive and highly significant across different estimation techniques. Moreover, the interaction between democracy in host country and foreign is positive and highly significant in the GMM specification, which is consistent and unbiased. Two points strengthen the results.

First, these results do not depend on the specific index of democracy. The results discussed above are based on the Freedom House index of democracy, which has the wider coverage. Regressions that use Polity II and the Przeworski et al. indices of democracy gives the same results (see the first three columns of Tables $2 \mathrm{a}$ and $3 \mathrm{a}) .{ }^{17}$

\footnotetext{
${ }^{16}$ In unreported regressions, I also experimented with difference GMM with qualitatively similar results.

${ }_{17}$ Glaeser et al. (2004) notes that several measures of democracy, including the polity II index from polity IV database, are in fact 'outcome' measures, which do not properly measure the constraint on government, which is the feature the 'institutionalists' would like to measure (North, 1981). To address this issue, I try also the variable 'constraint on the executive' from the polity IV database in unreported regressions; the results are confirmed.
} 
Second, all specifications, except the pooled OLS, include fixed country and fixed time effects; therefore, the results are robust to all county-specific time-invariant characteristics, including ethnic composition, religions, language, colonial ties, geographical variables, and many other unobservable characteristics, and to all world-wide trends, including higher income, trade, and education.

In conclusion, the results from these regressions show that the (lagged) total number of students abroad (normalized by the population) has no clear impact on democracy at home. In contrast, quality of democracy in host countries has a strong a significant impact on domestic democracy and this positive effect increases with the number of students abroad. ${ }^{18}$ In spite of these results two significant concerns are still at hand.

These results can be explained (1) by reverse causality if the choice of destination countries is endogenous or (2) by spurious correlation if common factors influence democracy at home and in host countries. The following two sections deal with the two issues.

\section{THE DETERMINATS OF FOREIGN EDUCATION AND REVERSE CAUSALITY}

The result that (lag) quality of institutions in host countries is correlated with democracy at home could be explained by reverse causality if the choice of destination country is endogenous. For instance, students from a dictatorial country may start going to more democratic countries in anticipation of more democracy at home. Chilean students in the early eighties started going predominantly to democratic countries before the Pinochet regime was dismissed, also in anticipation of future regime changes. Likewise, some eastern European students could have taken advantage of the move of their countries toward a more democratic regime in the late 80s to go abroad in anticipation of the return of democracy at home. ${ }^{19}$ Finally, repressive

\footnotetext{
${ }^{18}$ Note that the coefficient of total number of students abroad becomes positive and significant if the interaction term is excluded from the regressions.

19 The average quality of institutions in host countries is a weighted average of the index of democracy in the host countries so it changes also if the destination of students abroad changes.
} 
governments could start allowing their students to go abroad as a first move towards democracy. These factors point at the strong possibility of a reverse causality problem.

In principle, the GMM methodology already addresses this problem because lagged students and average level of democracy in host countries are treated as predetermined and are instrumented with their past levels and lags. All regressions pass the standard tests reported at the bottom of tables 1a, 2a, and $3 a{ }^{20}$ However, given the importance of reverse causality and to gain further insights on the determinant of the explanatory variables, I explore the issue in a more comprehensive manner in this section.

My strategy to address the issue of reverse causality is to use instruments based on predicted student flows; crucially, the predictions are obtained in a way that is independent of political variables and is not influenced by common factors (exclusion criterion for instruments). Before constructing these instruments, the determinants of bilateral students' flows are discussed.

The issue of reverse causality depends ultimately on the reasons as to why students go abroad and on the reasons behind the choice of the destination countries. Several studies point out at several explanations for student destination choices. Using two cross-sections of student data for 1969 and 1985, Kim (1998) finds a non-linear relationship between foreign students and difference in income, and that bilateral students' flows are larger when countries share the same religion or language. Using two cross-sections of student data for 1970 and 1989, Barnett and Wu (1995) find the existence of changing clusters in students' destinations indicating that, while "some western developed countries have remained at the center of the network, Asian and Middle Eastern countries have become more central." These studies show that the choice of destination countries is quite complex and seems mostly motivated by long-term time-invariant bilateral links, including colonial ties, language in common, distance, and proximity. Unfortunately, these variables cannot be used to build good instruments for students because

${ }^{20}$ For instance, Acemoglu et al. (2005a) use GMM and (long term) differences to claim that the correlation between democracy and education is spurious. 
these variables may also have a direct impact on (change in) democracy; moreover, these factors are time invariant and are ill-suited to construct time-varying instruments.

Focusing more on cyclical fluctuations, Sakellaris and Spilimbergo (2000) find that the enrollment of foreign students from low-income countries is positively correlated with the business cycle in home countries while enrollment from rich countries is negatively correlated with the business cycle in home countries. This suggests that the decision to study abroad is conditioned by economic factors as much as by political views. This study also shows that availability of grants is a crucial factor limiting the movement of students from low-income countries. This point constitutes the crucial motivation for the instrumental variable strategy as described below. Finally, the literature has focused only on long-term bilateral determinants or on economic fluctuations while political reasons for studying abroad have not studied, probably because it was perceived less relevant.

To understand the reasons behind bilateral student flows and to address the issue of reverse causality in a systematic way, I run the following regression:

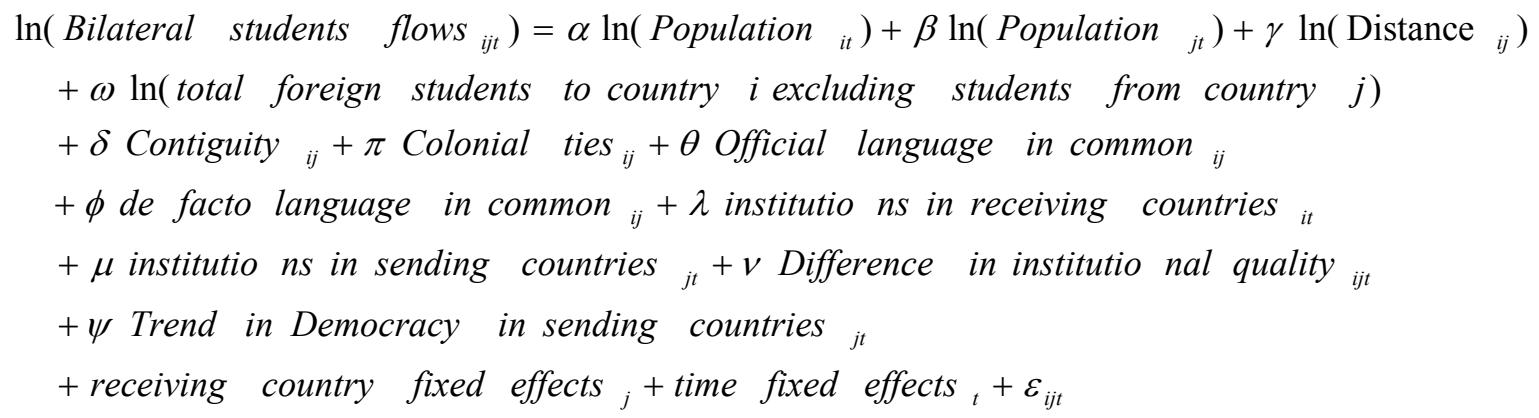

The control variables, which are suggested by the papers mentioned above, belong to four groups. A first set of variables, including distance, contiguity, colonial ties, official language in common, language in common spoken by more than 9 percent of the population, measure long term bilateral ties. A second set of variable - populations in both countries -are included as scale variables. A third set of variable are included to measure how political considerations play in the students' destination preferences: democracy in the sending country, democracy in the receiving 
country, the absolute difference in democracy indices between the two countries, and the trend in democracy in sending country (measured as the difference between the current and the fiveyear lagged levels of democracy). Fourth, in order to capture how open a country is to foreign students, I include a variable defined as the (log of) total students coming to country j, excluding students from country $\mathrm{i}\left[\equiv \ln \left(\sum_{s \neq i}\right.\right.$ Students $\left.\left._{s j t}\right)\right]$. This variable measures the popularity of country j, which may include the availability of grants, the easiness to enter the country, and the tradition in local universities, but avoids any tautological definition excluding bilateral student from i to j. Finally, I control for year and receiving country fixed effects to capture common trend and long-term time invariant characteristics of destination countries.

The equation above is estimated using the bilateral student flow database described in the appendix, which comprises almost 120,000 yearly bilateral observations. The results are reported in column 1 of Table $4 .{ }^{21}$ All variables have the expected sign as in a trade gravity equation. The four variables measuring political factors are particularly interesting for this paper. Less democratic countries send and receive fewer students; this captures the fact that the nondemocratic countries, especially the former soviet bloc, discouraged migration in general and, in particular, student flows. ${ }^{22}$ The coefficient on 'political distance,' measured by the absolute difference in democratic indices in sending and receiving countries, is strongly negative, indicating that students tend to go to countries with similar degrees of democracy as at home. The variable measuring the popularity of countries is positive and significant as expected. Finally, the variable measuring the effect of trend in democracy in the sending country is negative, indicating that countries worsening their democratic credential are sending more students abroad; this is consistent with the history of many Latin American countries whose students abroad increased after military take over (see the graph for Chile below). This finding is quite singular because it shows that foreign students seem to react to worsening of domestic

${ }^{21}$ Note that the large number of observations reduces significantly the size of the standard errors

${ }^{22}$ The fact that dictators have traditionally discouraged (or impeded) the migration of students to democratic countries suggests that indeed dictators were fully aware of the 'destructive' power of foreign education, even before reading the robustness tests in this paper! 
democracy by moving abroad. The R-squared of this gravity equation is .56, which is somewhat lower than what is commonly found in gravity equations in trade, but it is still quite high. Column (2) repeats the same specification with the exclusion of the democracy trend variable; the results do not change.

Column (3) reports the same specification excluding the three variables that are directly related to political preferences - levels of democracy in sending and receiving countries and absolute difference in the level of democracy. - The sign and the significance of all coefficients do not change and the R squared decreases only marginally from .56 to .51, showing that the political variables, even if significant, do not play a main role in explaining bilateral student flows. This is a first indication that the problem of reverse causality is, in practice, limited.

Besides political variables, a set of other bilateral variables, including distance, colonial ties, language in common, are possible determinants of democracy and bilateral students flows. For this reason, these variables cannot be used to construct the 'predicted student flows' to be used to explain democracy - their inclusion would violate the exclusion principle for instruments. The last column of table 4 presents a minimal specification in which only variables that have no impact on democracy at home, including population in the sending and receiving countries and the popularity of receiving countries among foreign students. In addition, I control for receiving country and year fixed effects. The R-squared decreases to .30, but it is still high, considering that only information on the receiving countries is used; this confirms the findings of abovementioned studies that conditions in receiving countries explain a large part of the time variation on the flows of students from non-OECD countries.

The bilateral student flows predicted used this last specification are, by construction, independent of any variable that may have any impact on the level of democracy in source countries. Therefore, predicted bilateral student flows using this specification provide a tool to produce an adequate instrument can be used to deal with the problem of reverse causality. This constitutes the rational for the construction of instrumental variables A.

\section{Instrumental strategy $\mathbf{A}$}


I use the predicted bilateral student flows from this specification to construct two variables: the predicted total annual students abroad, which is simply a sum over country of destination of the predicted bilateral flows, and the average democracy in receiving countries, which uses the actual democracy in host country weighted by predicted students according to the following formula: Predicted democracy in host countries ot $\equiv \sum_{d} \frac{\hat{S}_{o d t}}{\sum_{o} \hat{S}_{o d t}} D_{d t}$,

where $\widehat{S}_{o d t}$ is the predicted bilateral student flow from country o to country d at time t, using the last specification of table 4 column $4 ; D_{d t}$ is the degree of democracy in host countries. This is the same formula used to calculate actual democracy in host countries with the only innovation of predicted bilateral student flows rather than actual.

These two predicted variables are used in the GMM regressions as instruments for student flows and democracy in the host countries. ${ }^{23}$ Columns 1,3 , and 5 of table 5 report the result of the various democracy indices. The coefficients show remarkable stability in the GMM estimator (Table 1 Column 3) and GMM+ instruments (Table 5 Column 1) showing that the robustness of the results. The coefficients on average democracy in host countries remain strongly significant while the coefficient on the interaction term loses some significance. ${ }^{24}$ In conclusion, these regressions, which use constructed students' flow in a way that only exogenous variations are considered, show that political changes at home follow foreign education and not vice versa.

\section{Instrumental strategy $B$}

Bilateral student flows tend to be persistent over time. Past student flows have an impact on current flows but are not influenced by future political events. This consideration motivates the

${ }^{23}$ Technically, I use both level and differences of these instruments in the spirit of system GMM estimation.

${ }^{24}$ Note that in unreported regressions, I replicate the exercise using the predicted students flows based on the specification of column 3 Table 4, which has many more bilateral variables to explain bilateral student flows. The significance of the coefficients but the Hansen's specification test is lowered confirming that these instruments may be correlated with the dependent variable directly. 
construction of another instrument. I constructed the variable average democracy in host country using student flows 10 years before as weights to deal with this issue: ${ }^{25}$

$$
\text { Alternative predicted democracy in host countries }{ }_{o t} \equiv \sum_{d} \frac{\hat{S}_{o d t-10}}{\sum_{o} \hat{S}_{o d t-10}} D d t
$$

The variables constructed in this way are used as instruments as usual in the GMM context. Columns 2, 4, and 6 of table 5 report the result for different definitions of democracy.

Democracy in host countries and its interaction with the number of students abroad are strongly significant.

\section{Reverse causality?}

Overall, the previous literature and the student gravity regressions presented in this paper do not suggest that changes in the political situations in source countries play an overwhelming role in the choice of destination for foreign students. On the contrary, long-term links, including colonial ties and language in common, and economic factors play a fundamental role in explaining bilateral student flows.

Using these two facts, I construct two instruments, one using (change in) receptivity of host countries and the other using the high degree of persistency of student flows. Given the discussion above, these are good instruments because they are well correlated with the variable of interested - average level of democracy in host countries - but do not influence the level of democracy in host countries independently. ${ }^{26}$ Regressions using these variables as instruments indicate that there is little evidence that the correlation between foreign education and changes in democracy is due to reverse causality.

\footnotetext{
25 Note that lagged student flows are considered zero when inexistent. Given that students are used with a lag of 5 years, this poses a problem for the observations before 1970. This is the main reason why it is problematic to use longer lags.

${ }^{26}$ Besides the economic logic, these instruments pass the standard statistical tests as reported at the bottom of table 5 .
} 


\section{OMITTED VARIABLES AND SPURIOUS CORRELATION}

In principle, the correlation between democracy at home and (past) democracy in host countries could be spurious if third factors (e.g. the fall of communism) have an impact on democracy at home and (past) democracy in host countries. Because all regressions include time dummies that control for global trend, a possible bias may only arise when there are trends common to sending and host countries (club effect).

The variable democracy in host countries captures (part of) this club effect. Even controlling for this effect, the interaction term between democracy in host countries and number of students abroad is strongly significant across different definition of democracy (columns 3 of tables 1 a, 2a, and 3a). This indicates that countries benefit from movement toward democracy when they have more students abroad even when accounting for the club effect.

In order to probe further the issue of possible spurious correlation, I replicate the basic regression (column 3 in tables 1a, 2a, and $3 \mathrm{a}$ ) introducing possible third factors or omitted variable, including democracy in neighboring countries, education attainment, democracy in trading partners, and GDP per capita. These variables have been suggested as possible determinants of democracy and may have an impact on democracy. This list excludes all timeinvariant determinants of democracy, which are controlled by the country fixed effects. Finally, I present estimation in (short-run and long-run) differences and using GMM with long lags as instruments.

Regional patterns in democracy are well known and are a possible omitted factor. For instance, Asian countries displayed less democracy in the 1950s and 1960s, Latin American countries had a wave of dictatorships in the 1960s and 1970s, and African countries have had a long period of undemocratic regimes starting in the 1960s (Acemoglu and Robinson, 2005). The existence of regional trends begs the question of whether the variable democracy in host is mainly capturing regional trend; the question is even more justified given that bilateral student flows are strongly dependent on distance and contiguity (see table 4). In order to address this issue, I add a variable measuring democracy in neighboring countries (see appendix for the 
construction of this variable) to the baseline regression (column 3 in table 1a). The results, which are shown in column 4 of table 1 a for the freedom house index, show that democracy in neighboring countries is indeed significant but democracy in host countries remains positive and strongly significant. Similar results are obtained using the other two indices of democracy, polity II and Przeworski et al. (tables $2 \mathrm{a}$ and $3 \mathrm{a}$ ).

Educational attainment is also a possible omitted factor. For this reason, column 5 includes the variable educational attainment, which is available only for a sub-sample of countries for which students abroad are available. As a consequence, the sample decreases substantially. Education attainment is the variable that the previous literature on domestic education and democracy (e.g. Acemoglu et al, 2005a, and Glaeser et al., 2006) has focused on. In this specification, the variables measuring the quality of democracy in host country and education attainment are both positive and strongly significant. This is partly because these measures of democracy reduce the sample and partly because of differences in the construction of the indices (see Acemoglu and Robinson, 2005). These results are similar using the polity II and the Przeworski et al. indices of democracy (results reported in tables $2 \mathrm{a}$ and $3 \mathrm{a}$ respectively).

A third possible omitted variable is trade and, generally, long-term relationships with other nations. The idea that economic and political integration and democracy are intertwined has been suggested previously but has received only mixed empirical confirmation ( $\mathrm{Li}$ and Reuvey, 2003; Rigobón and Rodrik. 2005; and López-Córdova and Meissner, 2005). If studying abroad, especially in democratic countries, is only a particular aspect of globalization, then the significance of the coefficient on lagged democracy of host countries could be due to a spurious correlation. In order to check this hypothesis, I construct the variable "democracy in trading partner," which is an average of the democracy index in the trading partners using export share as weight. Column 6 of Table 1a presents the results of a regression in which this variable is added as a control. Despite the high correlation between democracy in trading partners and democracy in host countries (the correlation between democracy in trading partners and democracy in host countries is about .45 in the sample), average democracy in host countries 
and the interaction term remains highly significant, indicating that foreign education plays a role even when controlling for international trading ties. ${ }^{27}$

A fourth possible concern is that foreign students are really proxying for the flow of domestic students with tertiary education. Usually, the studies on democracy and education, including Acemoglu et al. (2004) and Glaeser et al (2006), use a stock variable such as average attainment as a proxy for education because the theoretical explanations on the link between democracy and education emphasize that the stock of education is important (e.g. Lipset, 1959). In line with these papers, specification 7 of tables 1 to 3 controls only for the stock of education (education attainment) and not for the flow (tertiary enrollment). ${ }^{28}$ The coefficients on democracy in host countries and interaction term remain positive and highly significant when including domestic enrollment while enrollment is generally significant. Consistent with these findings in a crosssection of student flows to the US, Rosenzweig (2006) finds that number of universities in source countries is also correlated with the number of students to the US. ${ }^{29}$

A fifth important omitted factor could be income per capita. Several authors (Barro, 1999) have found that income and democracy appear to be correlated at least in the long run; however, the interpretation on this correlation is controversial (Acemoglu et al., 2005). Controlling for income per capita, the results do not change (column 8 of table 1a). The same results hold using the other definition of democracy (tables 2 and 3).

${ }^{27}$ Note that López-Córdova and Meissner (2005) using the polity IV dataset finds an effect of globalization of trade on democracy especially in the period before World War II; the evidence after World War II is more nuanced. In an unreported regression, I ran democracy against democracy in trading partners controlling only for domestic education using system GMM and I found that democracy in trading partners becomes significant.

${ }^{28}$ I use domestic tertiary enrollment so that domestic data are comparable to the variable for foreign students, which refers only to tertiary education.

${ }^{29}$ Interesting Rosenzweig (2006) also finds that the quality of foreign universities (measured as number of universities ranked in the top 200) is positively correlated with the number of foreign students to the US. These data are available only for a cross-section and do not allow a panel analysis. Moreover, quality of education is probably very stable over time and so it is captured in the country fixed effects. 
Finally, as a further robustness test, specification 9 in tables 1 to 3 includes all of the control variables mentioned above (democracy in neighboring countries, education attainment, democracy in trading partners, tertiary enrollment, and GDP per capita). The coefficient on level of democracy in host countries remains positive and significant. In this specification, the number of observations half the baseline and many explanatory variables are highly correlated; the reason the coefficients on GDP per capita and tertiary enrollment become insignificant is most likely multicollinearity.

These regressions show that the effect of foreign education is significant even when controlling for a series of omitted variables.

\section{First Differences}

In order to further investigate the issue of omitted variable, I estimate the baseline specification in differences. The rationale for this specification is to take out all the possible country specific effects. ${ }^{30}$ The specification is:

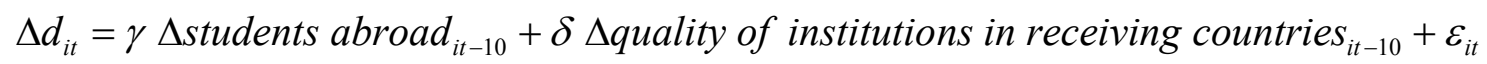

And

$$
\begin{aligned}
\Delta d_{i t} & =\gamma \Delta \text { students abroad } \\
& + \text { country }_{i 0}+\delta \text { fixed } \text { effects }_{i}+\varepsilon_{i t}
\end{aligned}
$$

The first specification controls for country fixed effects by taking differences; the second specification also controls for country specific trends (the fixed effects in differences). In addition, I try differences of 5 and 10 years. To avoid simultaneity bias, this specification has explanatory variables lagged five years in the 5-year specifications as well. The results are displayed in the first four columns Table 1b. Note that specifications 2 and 4 are extremely demanding given that they are in difference and with country fixed effects. As a result, the

\footnotetext{
${ }^{30}$ Note that fixed effects estimator assumes that the error terms are serially uncorrelated; in this case, the fixed effect estimators is more efficient than the first difference estimator. However, if only the first differences in the errors are uncorrelated, the first difference estimator should be used (Wooldridge, 2002).
} 
coefficients on democracy in host countries remain positive and significant but the interaction term loses significance.

\section{Long-run Differences}

Acemoglu et al. (2005) discusses the possibility that the link between education and democracy operates only with very long lags and suggests looking at long-run differences to find evidence of these effects. With long-run differences, it is not possible to control for country fixed effects. However, idiosyncratic country shocks should be less relevant in the long-run. I try the longest difference available with the present data using the following specification:

$$
\begin{aligned}
\Delta d_{i, 2000-1965} & =\alpha+\gamma \Delta \text { students abroad }_{i, 2005-1965} \\
& +\delta \Delta \text { quality of democ in receiving countries }{ }_{i, 2005-1965}+\varepsilon_{i t}
\end{aligned}
$$

The results for this specification are reported in column (5) of Table 1b; column (6) reports the same regression with the inclusion of (changes in) educational attainment. The coefficient on (changes in) democracy in host countries is always positive; when education attainment is introduced, the sample is reduced but the coefficient on democracy remains significant.

Figure 7 presents the scatter plot of changes in domestic democracy and changes in host countries' average democracy. The figure confirms that the significant correlation found in the regressions is not due to outliers.

\section{Long lags as instruments in GMM}

In GMM estimation technique, endogenous explanatory variables are instrumented by their own lagged levels and differences. The GMM regressions used in these papers used lags of five years. A possible problem could arise if the omitted variables (regional trend towards democracy) have an effect on democracy in host countries ten years ago and a democracy at home presently. For instance, this could be the case if the 'center' (let's say Soviet Union) anticipated the movement towards democracy, which reached some satellite countries only with more than ten year lag. In 
this case, the correlation between democracy at home and (past) democracy in host countries would be spurious. ${ }^{31}$

This possible spurious correlation could be solved by using sufficiently long lags of endogenous variables the base that it is highly unlikely that (non-global) trend in democracy in some countries more than 20 years ago had any impact on source country 20 years later. The costs of using long lags as instruments is that the longer the lag, the weaker is the correlation with present level of democracy in host countries, and so the weaker are the results. The other drawback of long lags is that the number of usable observation drop.

Despite this potential weakness, the results hold well using lags up to 20 to 25 years for all indices. ${ }^{32}$ This constitutes another piece of evidence that omitted variables are not responsible for the correlation between current democracy in source countries and past democracy in host countries.

\section{FURTHER ROBUSTNESS TESTS}

In addition to endogeneity and omitted variable bias, the results could be driven by the specification and/or sample heterogeneity. A first robustness test presents different specification for students; the remaining of the section focuses on heterogeneity along country size and time dimensions.

\section{Alternative Specification for Foreign Students}

So far, I have used three variables measuring the effects of students abroad on democracy at home - the number of students abroad, the average level of democracy in host countries and an interaction term.- While this is a way to summarize the plethora of data on bilateral student

\footnotetext{
${ }^{31}$ Foreign students in the 'center' could be able to absorb the new trends which are implemented when they go back to their own country. In this case, the correlation is not spurious; on the contrary, this would be a transmission channel through which foreign education spreads democracy. In this case, using long lags would actually ‘shut down' this channel and bias the results towards finding that foreign education is less important for democracy when in reality it is.

32 Regressions are available from the author upon request.
} 
flows, other aggregation are possible. In particular, foreign students could be classified into two categories: students going to fully democratic countries (for which the democracy index is 1) and students going to less than democratic countries (for which the index is less than 1). To check if my results depend on the specification proposed, I try this two-group specification. ${ }^{33}$

Note that this classification has the serious drawback that it does not distinguish between different degrees of democracy. The Freedom House and the Polity II indices provide a detail range of democracy, which is lost by aggregating foreign students into two categories. For instance, a student going to an almost democratic country with a score slightly below 1 is grouped together with a student going to a clearly dictatorial regime. For this reason, I prefer to use a weighted average of democracy in host countries rather than a category based on an arbitrary cut-off.

Using this binary classification, I replicate the baseline regression. Table 6 reports the results for various indices of democracy; in addition, I replicate the regression using the instruments discussed above for the number of students. ${ }^{34}$ All regressions confirm my basic results: democracy is positively associated with the number of students going to democratic countries but is clearly unrelated to the number of students going to non-democratic countries.

\section{Heterogeneity in the Sample - Time}

Before the eighties, when the cold war was raging, foreign education had a large political component (Richmond, 2003); while after the fall of Soviet Union foreign education lost the strong political association. In order to check for the presence of a structural break, I run the benchmark regression for the sub-periods before and after 1985. The results are in table 7.

\footnotetext{
33 As before, in order to make the number comparable among countries, the number of students is normalized by population.

34 The instruments for students to democratic and non democratic countries are constructed as before using predicted bilateral flows in a regression based on the specification of the last column of table 4 . The predicted bilateral flows are aggregated in two groups; students going to democratic and students going to non-democratic countries.
} 
For the years before 1985, the coefficients on democracy in host countries and the interaction terms are positive and highly significant. On the other hand, for the years after 1985 these coefficients lose significance when using the freedom house and the Przeworski et al. index.

These results suggest that the role foreign education on democracy was more important before 1985. ${ }^{35}$ This is not surprising given that the political component of foreign education was more important during the cold war period. This result should also be put in the framework of general trends in democracy. In the most recent decade, democratic status has been more stable (i.e. democratic countries remain democratic and dictatorships remain dictatorships) as is evident by comparing the coefficients on lagged democracy before and after 1985. In this context of relatively stability, foreign education is less relevant.

\section{Heterogeneity in the Sample - Country size}

Foreign education may be more relevant in small countries in which few individuals can make the difference than in large countries. Table 8 reports the results using 2 million as a cut-off figure. The evidence on country size and the effects of foreign education on democracy is unclear: using the Freedom house and the Przeworski indices, there is evidence that foreign education is more important in small countries while using the polity II index, the evidence is inconclusive.

In order to check that a particular group of countries does not drive the results, I also replicated the regressions using a sample restricted to non-socialist or to non-OECD countries with the same results. ${ }^{36}$ In conclusion, there is no evidence that heterogeneity plays a role in explaining the results.

\footnotetext{
${ }^{35}$ Note that the number of observations considerably smaller in the two sub-samples, especially for the Polity II and Przeworski indices after 1985. The reduced time dimension also reduces the feasibility of GMM; most of the specifications do not pass the Hansen's J test.

${ }^{36}$ Regressions are available on request.
} 


\section{STAY RATES}

One final concern that may arise is the effect of students who do not return to their home countries. In principle, foreign educated students may have an impact on the democracy of their home country both if they stay abroad and if they return home. For instance, expatriate communities have played a large role in the politics of Iraq or Afghanistan. However, the effect of foreign educated students on the democracy of home country is probably larger when students come back to their own country. For this reason, I take a closer look at stay rates of foreign students.

Unfortunately, there is no systematic dataset on return rates of foreign students but several sources may help. Usually, host countries give foreign students only temporary visas that are not automatically converted in other types of visa, and this limits the legal stay rate. For example, Borjas (2002) reports that, between 1971 and 1991, over 3 million people received a student VISA but only 393,000 received a permanent visa status at the end of the studying period. ${ }^{37}$ Rosenzweig (2006) points out that both Borjas (2002) and Bratsberg (2005) use data on border flows (admittances) and not the number of persons admitted with visas. Unfortunately, the discrepancy between the two concepts (and numbers) is so large that the numbers quoted before are only a rough indication of stay rates.

In addition to the VISA counting, there are three methods to estimate stay rates, although they have several limitations. The first method is looking at the level of education of foreign born individuals from the US census data (Carrington and Detragiache, 1998). This method has the drawback that the census does not specify where the individuals were educated and hence cannot be used in the present study. The second method for estimating stay rates uses data from tax authorities on foreign graduates who pay social security after graduation. Using this

\footnotetext{
${ }^{37}$ Borjas (2002) also observes that many student VISA recipients could have stayed illegally. For instance, about 300,000 illegal aliens who received amnesty after IRCA had temporary VISAs, including student VISAs. Using a similar methodology, Bratsberg (2005) finds that stay rates vary widely across countries, depending on the economic and political conditions in source countries.
} 
methodology, Baker and Finn (2003) estimate that 51 percent of the foreigners who graduated in the US in 1994/95 paid taxes in 1999 with a peak at 63 percent for students in computer science and engineering and much less for other disciplines. Finn (2001) provides estimates of stay rates by country of origin applying this technique (see table 9). China and India, the two most populous countries, have by far the highest rate of stay; excluding China and India, the stay rate for graduates decreases from 53 to 39 percent. The third method for estimating stay rates uses a survey of students' future plans (Doctorate Recipients from US Universities, 2004) and is likely the most imprecise because it is based on stated intentions. Column 3 of table 9 reports the staying intentions of non-US citizen doctorate recipients from different countries. Despite the fact that intentions of staying are always higher than actual rates, the broad patterns across countries are reproduced - students from India and China have a disproportionately high staying rate. Note that the data using the last two methods cover only graduate students. Finally, there is evidence that the stay rate has been increasing until the mid-nineties and has leveled off since (Finn, 2003). For instance, Glaser (1979) noted that “...the commitment to home country is very strong. Most students from developing countries plan to return home.”

One interesting observation from table 9 is that the stay rates seem to be much higher for students coming from very populous countries such as China and India. This suggests that graduating students have more incentives to go back in relatively small countries where they can 'make the difference' participating in the political life, while there may only be an economic incentive to go back to a very large country. The third largest stay rate is for Canada, for which returning students do not make a difference given the established democratic tradition. I take this as a further evidence that foreign educated students return especially to countries in which the "make the difference."

In conclusion, even in the US with a relatively flexible labor market and with a buoyant demand for highly skilled individuals, the stay rates have not surpassed fifty percent for the majority of sending countries. Other receiving countries probably have much lower stay rates. 


\section{INTERPRETATION AND CONCLUSIONS}

A large amount of resources are spent on foreign education with the explicit goal of educating individuals and fostering a particular system of values: Western countries have hoped to foster democracy, Socialist countries have educated future socialist leader, and Muslim countries have financed schools with Islamic values. Were these resources spent fruitfully?

This paper answers this question by looking at the most comprehensive existing dataset on foreign students, which spans 50 years and covers the entire world. Using this dataset and three different indices of democracy, I have found a very strong correlation between the lagged average indices of democracy in host countries and the current level of democracy in the origin country while there is only mixed evidence on the lagged total number of students abroad and the level of democracy at home.

These correlations are robust to the inclusion of several control variables, including education attainment at home, average level of democracy in trading partners, GDP per capita, country fixed effects, time fixed effects, different definitions of democracy, country specific trends, and exclusion of socialist countries or particular regions. Finally, these correlations generally hold even in differences with country specific trends.

A fundamental contribution of this paper is to propose two instrumental strategies to test the causality of the relationship between foreign education and democracy. The first instrument is based on a set of variables measuring how receptive are recipient countries to foreign students. The second instrument uses past student flows. In addition, a set of tests excludes the possibility of spurious correlation. The tests include modeling specific variables such as democracy in trading partners, using differences and long differences, as well as using GMM with very long lags. All these methodologies consistently rule out the possibility that the correlation between current democracy at home and past democracy in host countries is spurious.

These findings beg three questions: 1) how can a small minority be so influential, especially considering that many foreign students do not go back to their home country? 2) How does this 
paper contribute to the current debate on the relationship between education and democracy? 3) What are the specific mechanisms through which foreign educated individuals bring about changes in democracy at home?

The answer to the first question is part of the more general debate on the role of single leaders or restricted elites in history. The idea that elites are responsible for important changes has a long tradition in sociology; for instance, Parson (1960) writes that "... within the existing elites, such people are most likely to be found among intellectuals, especially those who have direct contacts with the west, particularly through education abroad or under western auspices at home." (Italics added). Lipset (1960) looks at the specific case of elites in Latin America. ${ }^{38}$ More recently, Jones and Olken (2005) have found that leaders do matter for countries' income growth. This paper adds another piece of evidence to this intellectual tradition showing how foreign education of the elites may explain the course of history. Table 11 presents the level of education and the location where world leaders in 1990 studied. ${ }^{39}$ Out of 115 world leaders, 66 studied abroad; the percentage of foreign-educated leader increases to more than two thirds if only developing countries are considered. These numbers show clearly that foreign educated individuals do play an overwhelming role in their own home countries.

The second issue is how these findings contribute to the current debate on the relationship between domestic education and democracy (see Glaeser et al., 2006, and Acemoglu et al., 2005). The evidence presented shows that quality of foreign education matters for democracy. I have also shown that foreign education is not due to long-term omitted variables, by incorporating fixed effects and showing long-run differences. Is this the ultimate proof that education matters for democracy? No, because foreign education is very different from domestic education on

\footnotetext{
${ }^{38}$ For an interesting discussion and convincing case on how a small group of foreign educated economists had a huge impact on Chile see Valdés (1995).

39 Table 11 presents the level of education of world leaders in 1990 as identified by Jones and Olken (2005). The information on education was collected by checking biography of each leader. If no information was available a missing value is indicated. Therefore, the numbers of table 11 are a lower bound for the actual number of foreign educated leaders.
} 
which this debate is focused. First, foreign educated people are only a restricted minority of the population, by far less numerous than the domestically educated people. Second, I have shown that quality of foreign education matters, so I do not find evidence for the hypothesis that education per se matters because it teaches the value cooperation and lower the cost of organization of civil society. This leaves open the question of how important is the educational level of the elites is in explaining economic and political outcomes.

The third issue is understanding through which specific mechanisms foreign educated individuals bring about changes in democracy at home. Many hypotheses are possible and are compatible with the available evidence. First, foreign educated technocrats are such a scarce resource in many countries that they can impose their own preferences in favor of democratic regimes; in other words, there are no alternatives other than hiring a foreign educated minister who accepts the job only if a country has a reasonable level of democracy. In some sense, this happened when Gorbachev decided to reform the soviet system and during the Yeltsin era. The old soviet bureaucrats simply were unable to handle the new economic challenges while the new 'technocrats' were available under a democratic regime. In addition, a foreign educated minister could provide confidence to foreign investors. Second, foreign educated leaders seem to be extremely motivated to introduce democracy and to keep up with the more developed countries where they studied; in general, the leaders' educational level seems to be associated with the probability of introducing structural reforms (Dreher et al., 2006). ${ }^{40}$ Third, foreign educated individuals make it more difficult for dictatorial regimes to maintain repression by spreading new ideas at home. Fourth, foreign educated individuals can make repressive activities more costly for a dictatorial regime as they have easier access to external media; in addition, foreign educated individuals may lobby foreign governments to press changes at home. Fifth, education abroad may inculcate a sense of common identity with the international democratic community; this

\footnotetext{
${ }^{40}$ Based on a survey on the reasons for pursuing a $\mathrm{PhD}$ in the US, Aslambeigui and Montecinos (1998) find that "the significance attributed to a $\mathrm{PhD}$ in careers in politics seemed especially strong among students from Latin America, where economists are currently playing very important political roles."
} 
sense of common identity has proven a very powerful motivating factor (see Akerlof and Kranton, 2005). ${ }^{41}$ Future work should study which specific channels are at work.

The conclusions of this paper also have implication for the debate on nation-building. The education of foreigners has always being a cornerstone of US's foreign policy; from the missionary thrust into Latin America, to the cold war efforts, and to the present effort in Middle East (Bu, 2003). Foreign-educated elites also played a crucial role in former socialist countries. Recent attempts of introducing democracy have relied heavily on foreign educated leaders, including in Iraq and Afghanistan. This paper provides evidence that these are not isolated cases and foreign education does indeed play an important role.

The paper also contributes to the debate on the nature of political power in the XXI century. Influential scholars in international relations theory have argued that 'soft power,' defined as the ability of a political body to influence indirectly the behavior of other political bodies through ideological or cultural means without the use of coercion, will play an important role (Nye, 2004). Foreign education is listed as one of the main instrument to exert `soft power.' Despite its popularity and appeal, 'soft power' has proven remarkably difficult to test empirically. This paper provides a first quantification of an important component of 'soft power.'

Finally, this paper has argued that foreign education, which is only one aspect of education of the elites, matters for the type of regime in which they decide to live. This begs the question of whether other characteristics of the elites matter for the development of countries. Future research should focus on the elites' general educational level and, more generally, other characteristics, including attitudes toward markets, religion, and values.

${ }^{41}$ Several studies have found that foreign students develop a strong sense of identification for the country where they study (see Sellitz et al., 1963). For instance, Ye (2001) describes how "Chinese by studying at American universities played pivotal roles in Chinese intellectual, economic, and diplomatic life upon their return to China. These former students exemplified key aspects of Chinese "modernity," introducing new social customs, new kinds of interpersonal relationships, new ways of associating in groups, and a new way of life in general." 


\section{Data Appendix}

As dependent variable, I use three measures of democracy. The Freedom House's Political Rights Index ranges between 1 and 7, with 1 representing the most freedom. ${ }^{42}$ The index summarizes a number of dimensions, including the existence of free elections, of competitive parties. Following Barro (1999) and Acemoglu et al. (2004), I supplement this index with data from Bollen $(1990,2001)$ for 1960 and 1965. As a second measure of democracy I use the composite polity II index from the Polity IV dataset, which is the difference between the Polity's democracy and autocracy indices. ${ }^{43}$ Polity IV dataset contains coded annual information on regime and authority characteristics for all independent states (with greater than 500,000 total population) in the global state system and covers the years 1800-2003. The third measure of democracy is the dichotomous democracy index proposed by Przeworski, Alvarez, Cheibub, and Limongi (1990) and extended by Boix and Rosato (2001); a key aspect of this index is that a country is not considered a democracy unless a political party has lost power. This index is appealing for this paper because the dichotomous nature of the index makes is clear the year of transition. In order to make the results easier to interpret, I normalize the indices so that 1 corresponds to the maximum degree of democracy and 0 to the least.

My main explanatory variables - share of foreign students over population and average quality of institutions in host countries - are constructed from the cross country student migration database as reported in the UNESCO Statistical Yearbook. The database covers the time period 1950 to 2003 and refers to students' migration at the third tier of education (university education and higher). The data are produced by the receiving countries, which typically collect information from local institutions. In the 50s, the data are available for only few receiving countries including Australia, Austria, Belgium, Egypt, France, Germany, India, Japan,

42 The data updated to 2005 are available from the Freedom House's website (http://www.freedomhouse.org/).

43 The data are available from the Polity IV's website (http://www.cidcm.umd.edu/inscr/polity/). Note that the name of the variable is polity II in the dataset and throughout the paper. See Marshall and Jaggers (2006) for details on how the variable was constructed. 
Netherlands, Spain, Switzerland, UK, and US - countries that cover traditionally receive the majority of students- and for the 50 main sending countries. Starting with 1960, the data are available for almost all receiving countries and the majority of sending countries. Data were purged of evident outliers; ${ }^{44}$ missing data for bilateral flows for which there was sufficient non missing years were interpolated. Figure 1 shows total foreign students and foreign students normalized by world population and by tertiary enrollment.

The population and the real income per capita data come from the World Bank's WDI augmented with national sources whenever there are missing values.

The variable average democracy index in host countries is constructed as the weighted average of the institution in the host countries where the weights are given by the share of students from country $j$ to country I over all students from country $j$ :

$$
\text { Democracy in host countries }{ }_{\text {ot }} \equiv \sum_{d} \frac{S_{\text {odt }}}{\sum_{o} S_{\text {odt }}} D_{d t}
$$

Where $D_{d t}$ is one of the three democracy indices described above; $S_{o d t}$ is the number of students from country o to country d in year t. By construction, the three indices so constructed lies between 0 and 1 ; the index is 1 if all students abroad are democratic countries and 0 if all students abroad are in dictatorial regimes. In order to avoid problems of small sample, this variable is used only of there are at least 10 students abroad. Note that the countries weights are calculated for each year so the index for a specific country may change from year to year for two reasons: 1) if the level of democracy in host countries changes or 2) if the combination of students abroad changes.

The other control variables include education attainment from the Barro-Lee (2000) dataset, tertiary enrollment from the World Bank's WDI, democracy in trading partners, and democracy in neighboring partners. The variable democracy in trading partners is constructed as

${ }^{44}$ e.g. if the number of students from country A to country B was 10000 in one year when the average for the preceding and following decades was 10. 
the weighted average of the institution in the trading partners where the weights are given by the share of exports from country d to country o over all exports from country d:

$$
\text { Democracy in trading partners }{ }_{\text {ot }} \equiv \sum_{d} \frac{E X P_{\text {odt }}}{\sum_{o} E X P_{\text {odt }}} D_{d t}
$$

Where $D_{d t}$ is one of the three democracy indices described above; EXP ${ }_{\text {odt }}$ is the value of exports from country o to country d in year t. The Data on trade come from the UN's COMTRADE database. The variable democracy in neighboring partners is constructed as the weighted average of the institution in the neighboring countries where the weights are given by the population of country i divided by the distance from country $j$ to country $i$ :

$$
\text { Democracy in neighboring countries }{ }_{\text {ot }} \equiv \Sigma_{d} \frac{P o p_{d t}}{\text { Distance }_{o d}} D_{d t}
$$

Where $D_{d t}$ is one of the three democracy indices described above; Distance ${ }_{o d}$ is the distance between country o and country d.

The sample include all countries for which the data are available, which were independent for at least 5 years.

Table 10 presents the summary statistics. 


\section{FIGURES}

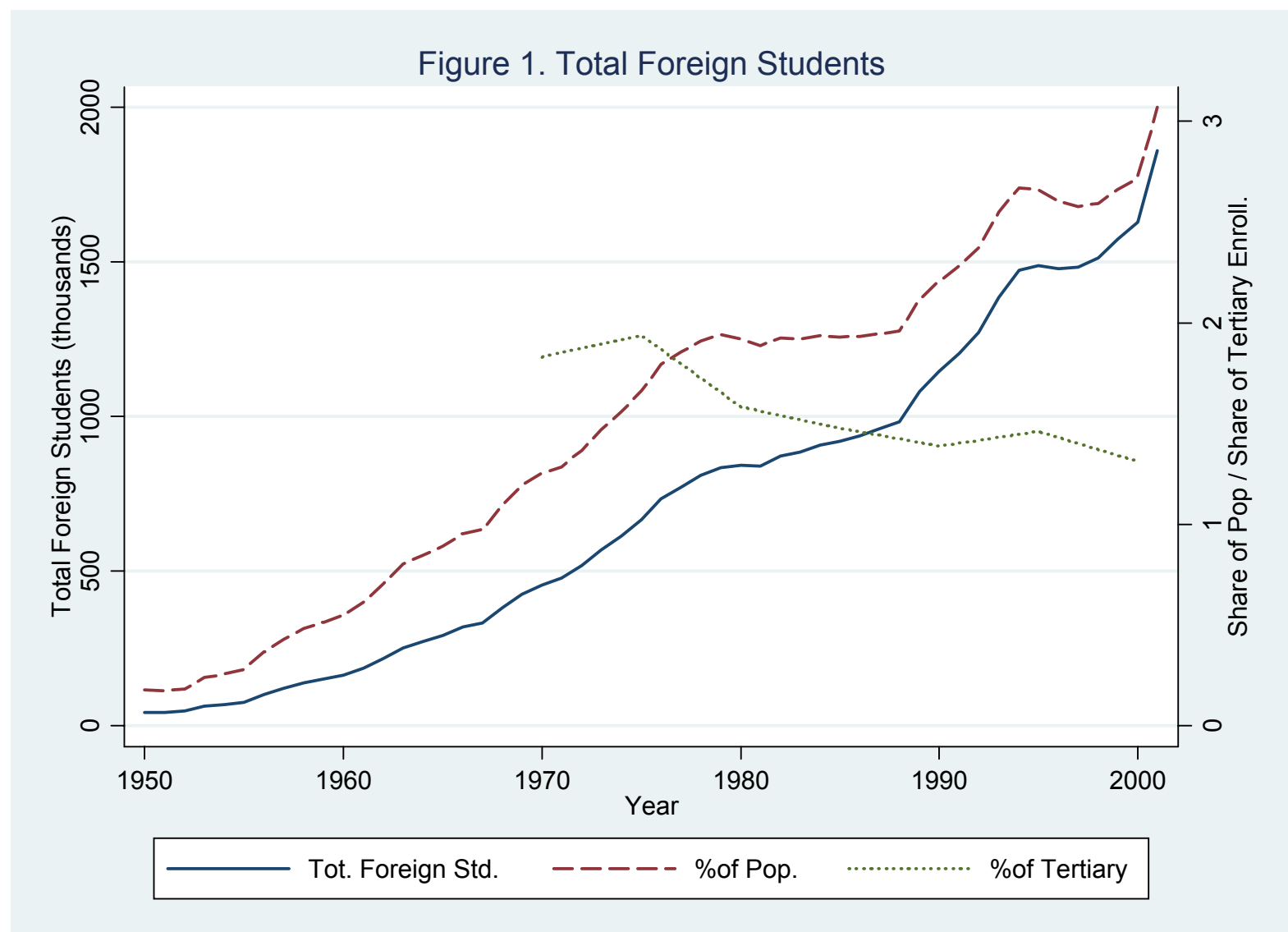

Note: the original data come from the UNESCO dataset revised as described in the Data Appendix. The solid line represents the total number of students abroad. The dashed line represents students abroad normalized by (millions of) individuals in the origin countries; the dotted line represents students abroad normalized by (tens of millions) of people getting tertiary education in the origin countries. 


\section{Figure 2. Host countries}

Shares of total foreign students
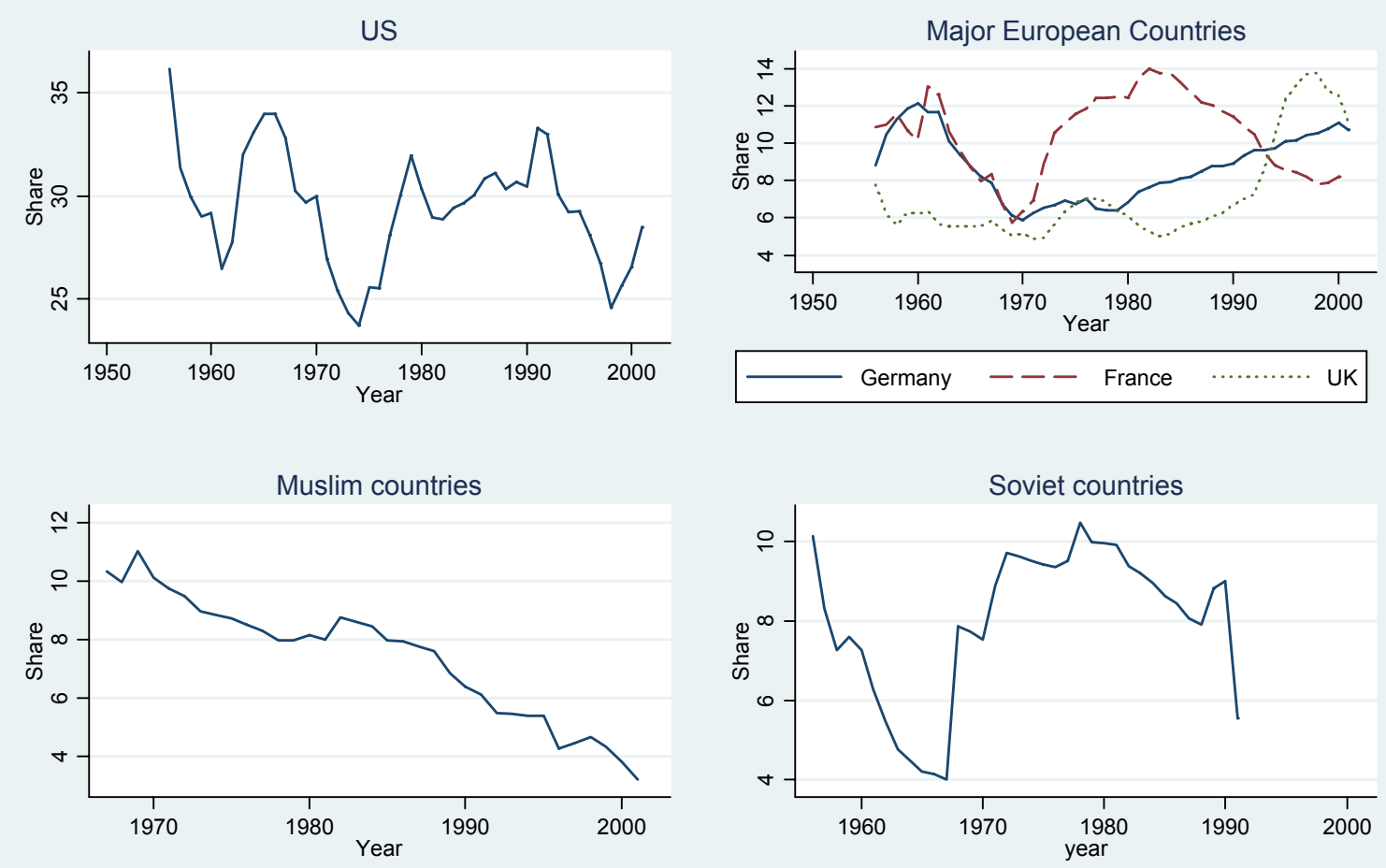

Note: the original data come from the UNESCO dataset revised as described in the Data Appendix.. 


\section{Figure 3. Chile}
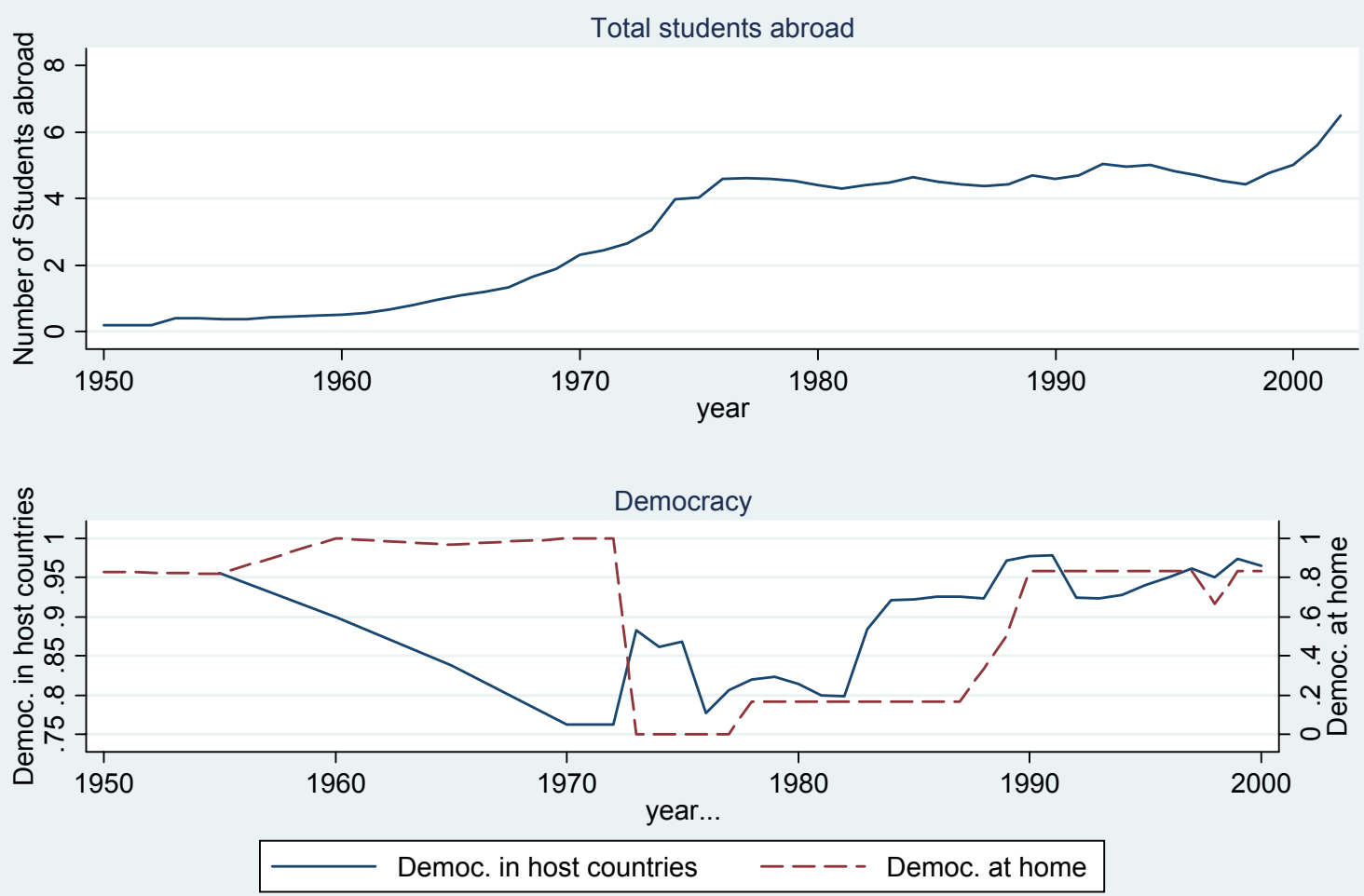

Note: the top panel shows total number of Chilean students abroad in expressed in thousands. The bottom panel shows the level of democracy in home country and in students' host countries, i.e. the average level of democracy in countries where Chilean students are. Both indices are constructed using the Freedom House index of democracy normalized so it lies between 0 and 1 . The construction of the data is described in the data appendix. 


\section{Figure 4. Argentina}
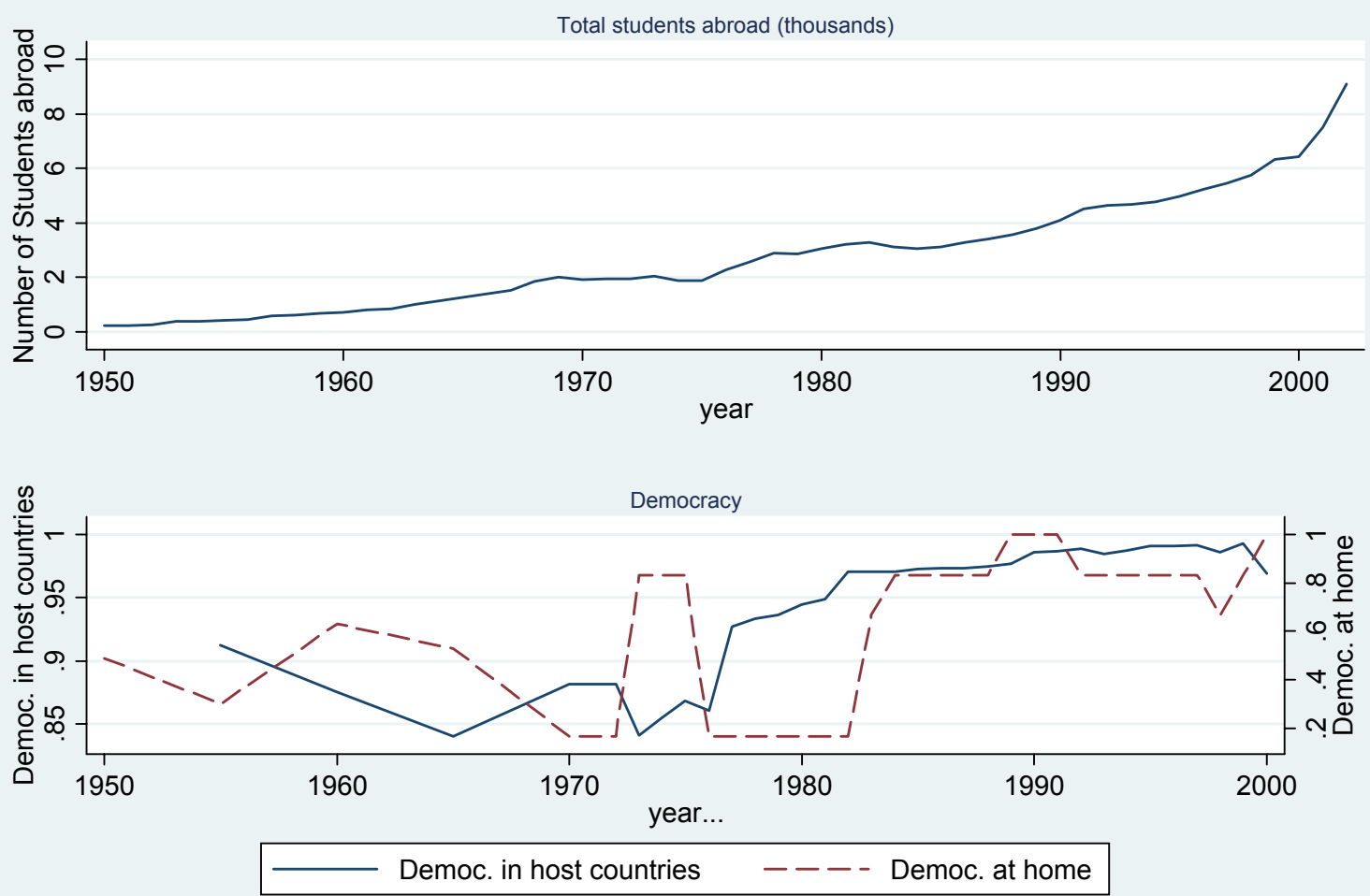

Note: the top panel shows total number of Argentinean students abroad in expressed in thousands. The bottom panel shows the level of democracy in home country and in students' host countries, i.e. the average level of democracy in countries where Argentinean students are. Both indices are constructed using the Freedom House index of democracy normalized so it lies between 0 and 1 . The construction of the data is described in the data appendix. 


\section{Figure 5. Iran}
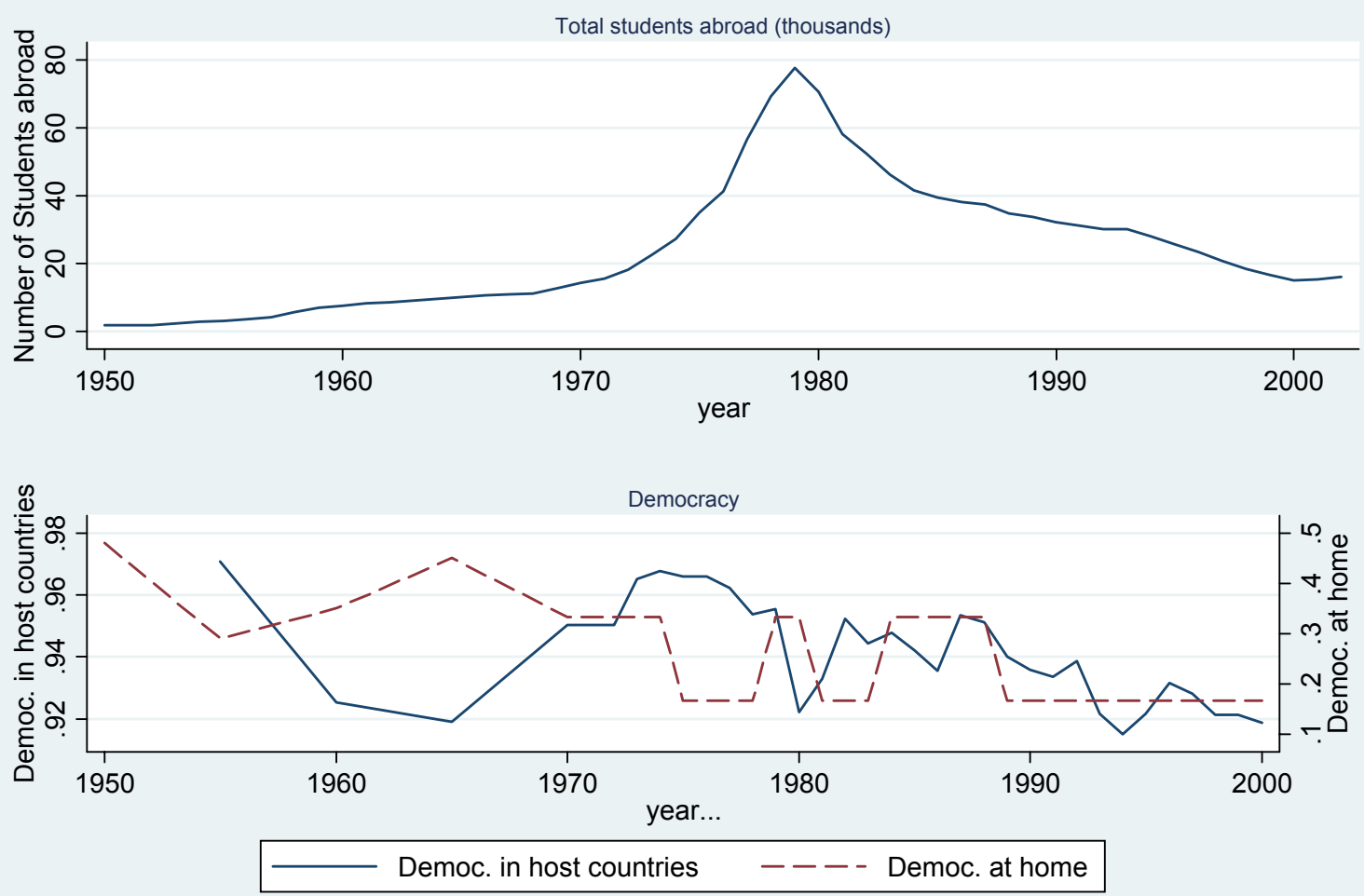

Note: the top panel shows total number of Iranian students abroad in expressed in thousands. The bottom panel shows the level of democracy in home country and in students' host countries, i.e. the average level of democracy in countries where Iranian students are. Both indices are constructed using the Freedom House index of democracy normalized so it lies between 0 and 1 . The construction of the data is described in the data appendix. 


\section{Figure 6. Korea}
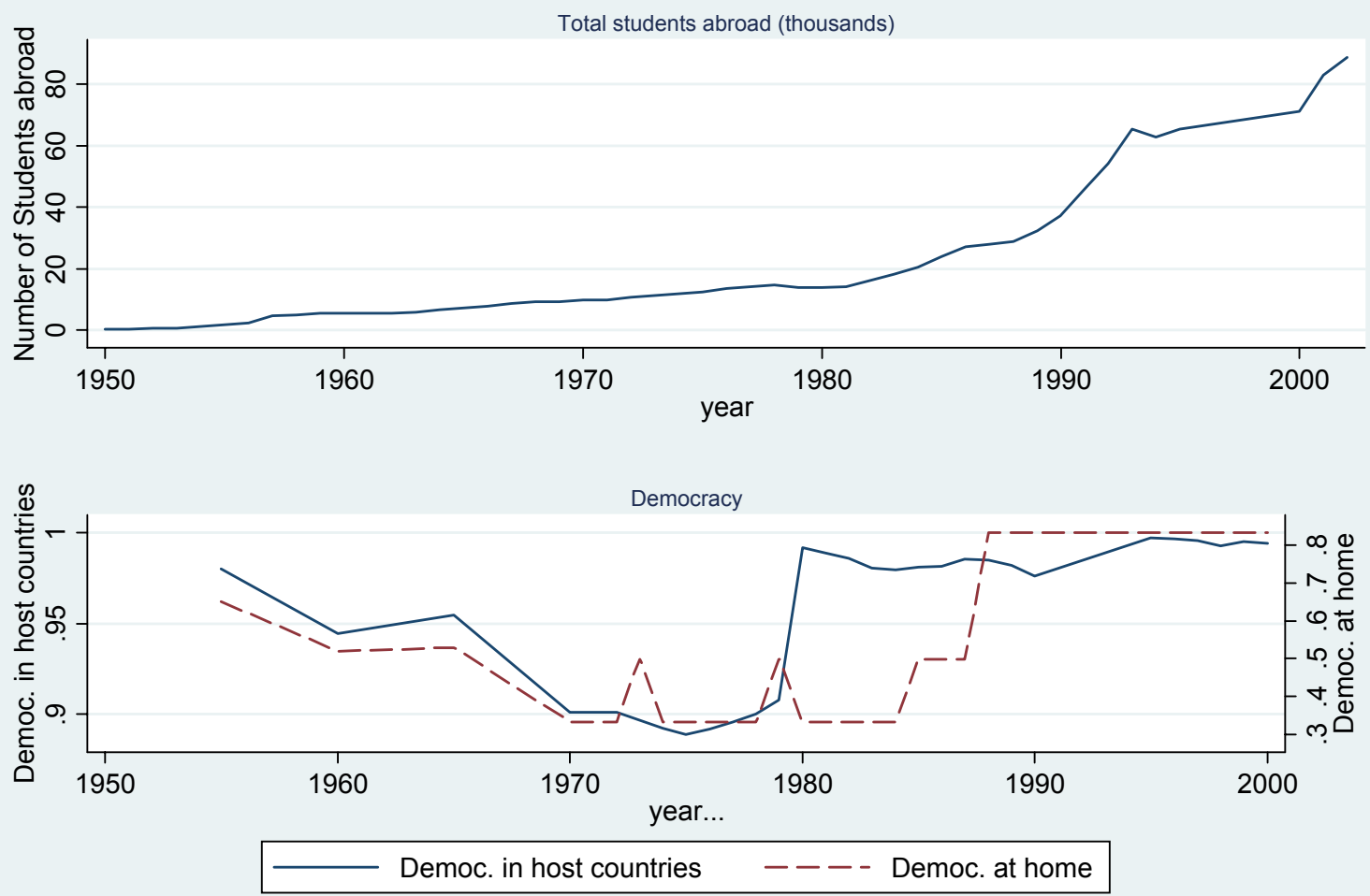

Note: the top panel shows total number of Korean students abroad in expressed in thousands. The bottom panel shows the level of democracy in home country and in students' host countries, i.e. the average level of democracy in countries where Korean students are. Both indices are constructed using the Freedom House index of democracy normalized so it lies between 0 and 1 . The construction of the data is described in the data appendix. 


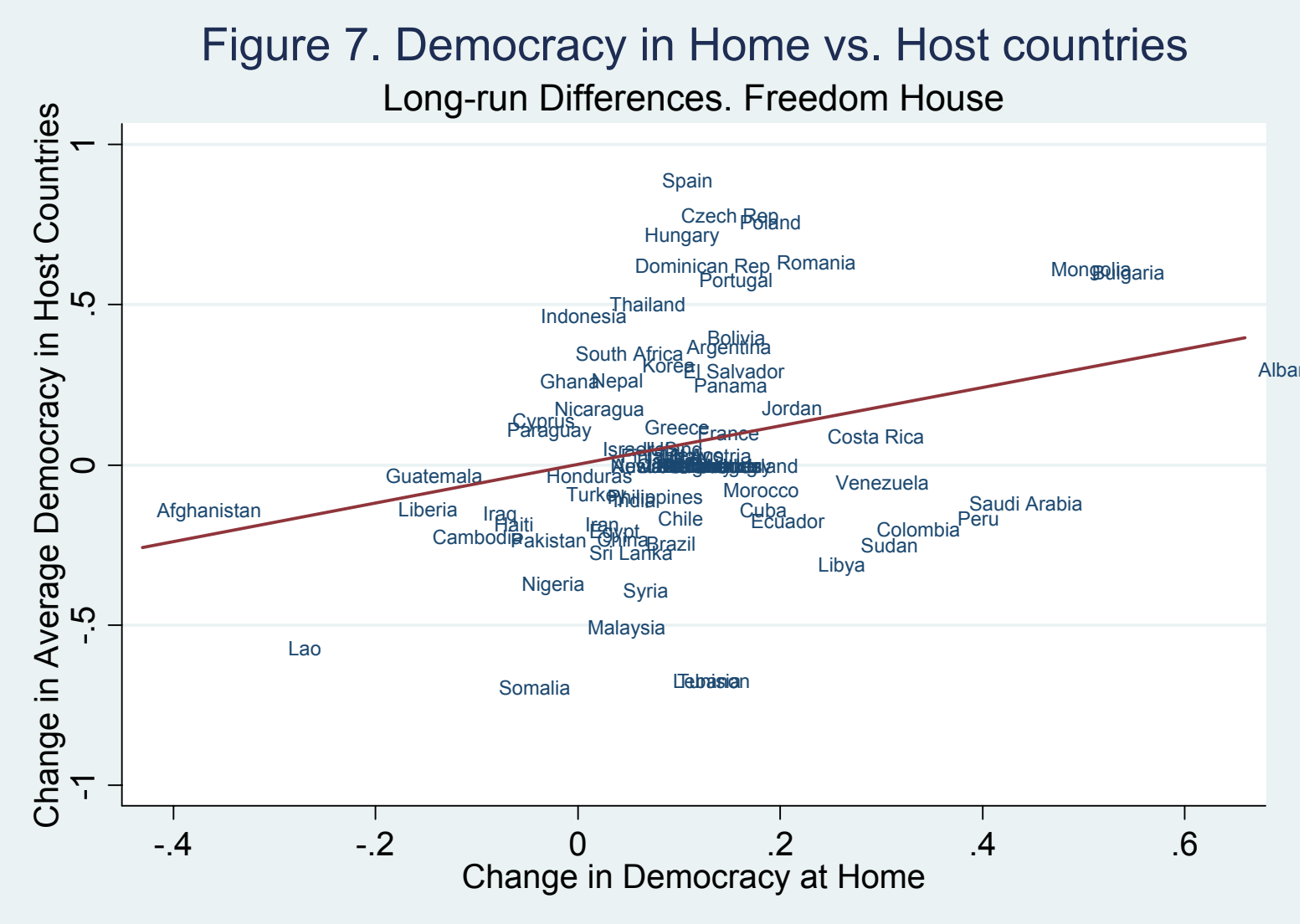

Note: the differences are taken in both cases between 1960 and 2000 . 
Table 1a. Dependent variable: Freedom house index of political freedom - Level

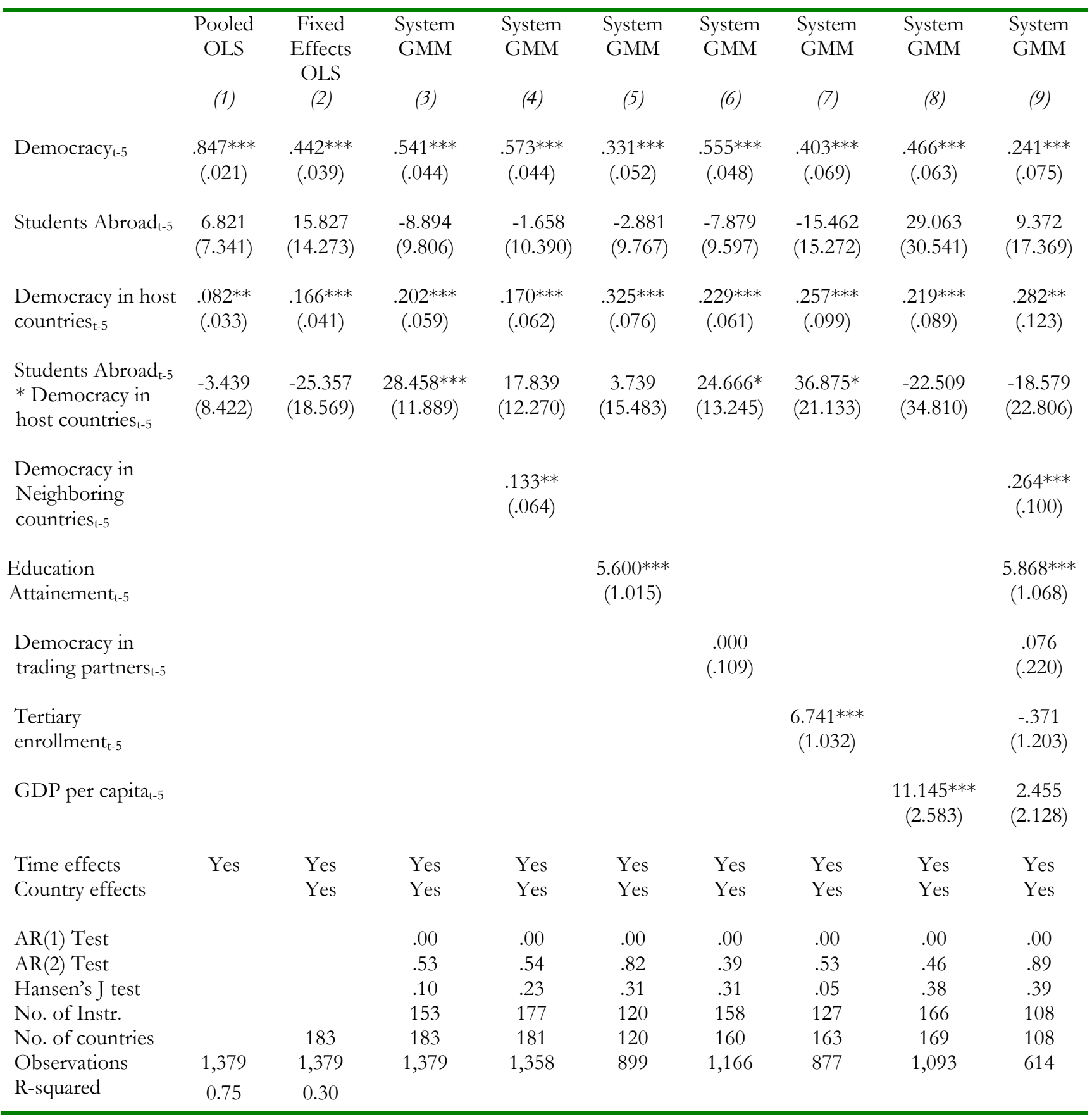

* significant at $10 \%$; ** significant at 5\%,*** significant at $1 \%$. Robust standard errors clustered by country in parentheses. $\mathrm{AR}(1)$ and $\mathrm{AR}(2)$ are Arellano-Bond test for serial correlations. The sample is an unbalanced panel, comprising data at five year interval between 1955 and 2005. Students abroad, democracy in host countries, and all other control variables are treated as predetermined and are instrumented for using their own first to third lags. 
Table 1b. Dependent variable: Freedom house index of political freedom - Differences

\begin{tabular}{|c|c|c|c|c|c|c|}
\hline & $\begin{array}{l}\text { Change in } \\
\text { Democracyt } \\
\text { (5 years) } \\
\text { OLS } \\
\text { (1) }\end{array}$ & $\begin{array}{l}\text { Change in } \\
\text { Democracyt } \\
\text { (5 years) } \\
\text { Fixed } \\
\text { Effects } \\
\text { (2) }\end{array}$ & $\begin{array}{l}\text { Change in } \\
\text { Democracy } \\
\text { (10 years) } \\
\text { OLS } \\
\text { (3) }\end{array}$ & $\begin{array}{l}\text { Change in } \\
\text { Democracyt } \\
\text { (10 years) } \\
\text { Fixed } \\
\text { Effects } \\
\text { (4) }\end{array}$ & $\begin{array}{l}\text { Change in } \\
\text { Democracyt } \\
\text { (40 years) } \\
\text { OLS } \\
\text { (5) }\end{array}$ & $\begin{array}{l}\text { Change in } \\
\text { Democracyt } \\
\text { (40 years) } \\
\text { OLS } \\
\text { (6) }\end{array}$ \\
\hline $\begin{array}{l}\text { 5-Year Change in Students } \\
\text { Abroad }_{t-5}\end{array}$ & $\begin{array}{c}6.699 \\
(7.609)\end{array}$ & $\begin{array}{c}6.947 \\
(8.420)\end{array}$ & & & & \\
\hline $\begin{array}{l}\text { 5-Year Change Democracy in } \\
\text { Host countries }_{\mathrm{t}-5}\end{array}$ & $\begin{array}{l}.077 * * \\
(.039)\end{array}$ & $\begin{array}{l}.071 * \\
(.040)\end{array}$ & & & & \\
\hline $\begin{array}{l}\text { 5-Year Change in (Students } \\
\text { Abroad }_{\mathrm{t}-5} * \text { Democ. in host } \\
\text { countries }_{\mathrm{t}-5)}\end{array}$ & $\begin{array}{l}-10.357 \\
(13.635)\end{array}$ & $\begin{array}{l}-12.056 \\
(17.494)\end{array}$ & & & & \\
\hline $\begin{array}{l}\text { 10-Year Change in Students } \\
\text { Abroad }_{t}\end{array}$ & & & $\begin{array}{l}38.209 \\
(23.777)\end{array}$ & $\begin{array}{l}37.265 \\
(23.269)\end{array}$ & & \\
\hline $\begin{array}{l}\text { 10-Year Change in Democ. in } \\
\text { Host Countrie }_{t}\end{array}$ & & & $\begin{array}{l}.209 * * * \\
(.077)\end{array}$ & $\begin{array}{c}.188^{* *} \\
.082\end{array}$ & & \\
\hline $\begin{array}{l}\text { 10-Year Change in (Students } \\
\text { Abroad }_{\mathrm{t}-10} * \text { Democ. in Host } \\
\text { Countries }_{\mathrm{t}-10)}\end{array}$ & & & $\begin{array}{l}-46.076^{*} \\
(26.131)\end{array}$ & $\begin{array}{l}-48.623 * \\
(29.337)\end{array}$ & & \\
\hline $\begin{array}{l}\text { 40-Year Change in Students } \\
\text { Abroad }_{t}\end{array}$ & & & & & $\begin{array}{c}26.308 \\
(75.369)\end{array}$ & $\begin{array}{c}67.556 \\
(115.848)\end{array}$ \\
\hline $\begin{array}{l}40-\text { Year Change Democracy in } \\
\text { Host Countries }_{t}\end{array}$ & & & & & $\begin{array}{c}.652^{* * *} \\
(.139)\end{array}$ & $\begin{array}{c}.522 * * * \\
(.162)\end{array}$ \\
\hline $\begin{array}{l}\text { 40-Year Change in (Students } \\
\text { Abroad }_{\mathrm{t}} * \text { Democ. in Host } \\
\left.\text { Countries }_{\mathrm{t}}\right)\end{array}$ & & & & & $\begin{array}{l}-19.934 \\
(79.571)\end{array}$ & $\begin{array}{c}-64.065 \\
(127.287)\end{array}$ \\
\hline $\begin{array}{l}\text { 40-Year Change in Education } \\
\text { Attainement } t_{t}\end{array}$ & & & & & & $\begin{array}{l}-1.181 \\
(2.969)\end{array}$ \\
\hline Country Effects & & Yes & & Yes & & \\
\hline $\begin{array}{l}\text { No. of countries } \\
\text { Observations } \\
\text { R-squared }\end{array}$ & $\begin{array}{c}160 \\
1,073 \\
.00\end{array}$ & $\begin{array}{c}160 \\
1,073 \\
.00\end{array}$ & $\begin{array}{l}159 \\
513 \\
.02\end{array}$ & $\begin{array}{r}159 \\
513 \\
.02\end{array}$ & $\begin{array}{l}85 \\
85 \\
.21\end{array}$ & $\begin{array}{l}68 \\
68 \\
.11\end{array}$ \\
\hline
\end{tabular}

* significant at $10 \%$; ** significant at 5\%,*** significant at $1 \%$. Robust standard errors clustered by country in parentheses. The sample is an unbalanced panel, comprising data between 1955 and 2005. 
Table 2a. Dependent variable: Polity2

\begin{tabular}{|c|c|c|c|c|c|c|c|c|c|}
\hline & $\begin{array}{l}\text { Pooled } \\
\text { OLS } \\
\text { (1) }\end{array}$ & $\begin{array}{c}\text { Fixed } \\
\text { Effects } \\
\text { OLS } \\
\text { (2) }\end{array}$ & $\begin{array}{c}\text { System } \\
\text { GMM } \\
\text { (3) }\end{array}$ & $\begin{array}{c}\text { System } \\
\text { GMM } \\
\text { (4) }\end{array}$ & $\begin{array}{c}\text { System } \\
\text { GMM } \\
\text { (5) }\end{array}$ & $\begin{array}{c}\text { System } \\
\text { GMM } \\
\text { (6) }\end{array}$ & $\begin{array}{c}\text { System } \\
\text { GMM } \\
\text { (7) }\end{array}$ & $\begin{array}{c}\text { System } \\
\text { GMM } \\
\text { (7) }\end{array}$ & $\begin{array}{c}\text { System } \\
\text { GMM } \\
\text { (9) }\end{array}$ \\
\hline Democracy $_{\mathrm{t}-5}$ & $\begin{array}{c}.830 * * * \\
(.022)\end{array}$ & $\begin{array}{l}.452^{* * *} \\
(.047)\end{array}$ & $\begin{array}{l}.409 * * * \\
(.064)\end{array}$ & $\begin{array}{c}.491 * * * \\
(.061)\end{array}$ & $\begin{array}{c}.288^{* * *} \\
(.073)\end{array}$ & $\begin{array}{c}.424^{* * *} \\
(.065)\end{array}$ & $\begin{array}{l}.338^{* * *} \\
(.078)\end{array}$ & $\begin{array}{c}.497 * * * \\
(.085)\end{array}$ & $\begin{array}{l}.300^{* * *} \\
(.082)\end{array}$ \\
\hline Students Abroad $_{\mathrm{t}-5}$ & $\begin{array}{c}2.487 \\
(5.964)\end{array}$ & $\begin{array}{c}24.229 * * * \\
(8.621)\end{array}$ & $\begin{array}{l}-12.382 \\
(12.116)\end{array}$ & $\begin{array}{l}-9.658 \\
(11.136)\end{array}$ & $\begin{array}{l}-18.645 \\
(12.150)\end{array}$ & $\begin{array}{l}-15.735 \\
(13.321)\end{array}$ & $\begin{array}{c}-35.058^{* * *} \\
(12.645)\end{array}$ & $\begin{array}{l}-15.377 \\
(19.694)\end{array}$ & $\begin{array}{c}-53.085^{* *} \\
(25.672)\end{array}$ \\
\hline $\begin{array}{l}\text { Democracy in host } \\
\text { countries }_{t-5}\end{array}$ & $\begin{array}{c}.100 * * * \\
(.036)\end{array}$ & $\begin{array}{l}.116^{* *} \\
(.052)\end{array}$ & $\begin{array}{l}.355^{* * *} \\
(.071)\end{array}$ & $\begin{array}{l}.310^{* * *} \\
(.074)\end{array}$ & $\begin{array}{c}.409 * * * \\
(.098)\end{array}$ & $\begin{array}{l}.349 * * * \\
(.074)\end{array}$ & $\begin{array}{l}.327 * * * \\
(.110)\end{array}$ & $\begin{array}{c}.298^{* * *} \\
(.087)\end{array}$ & $\begin{array}{c}.416^{* * *} \\
(.125)\end{array}$ \\
\hline $\begin{array}{l}\text { Students Abroad }{ }_{\mathrm{t}-5} \\
* \text { Democracy in } \\
\text { host countries }_{\mathrm{t}-5}\end{array}$ & $\begin{array}{l}-3.880 \\
(7.044)\end{array}$ & $\begin{array}{c}-33.712^{* * *} \\
(12.458)\end{array}$ & $\begin{array}{c}25.658^{* *} \\
(12.904)\end{array}$ & $\begin{array}{l}20.544^{*} \\
(12.274)\end{array}$ & $\begin{array}{l}25.473^{*} \\
(13.190)\end{array}$ & $\begin{array}{c}29.379 * * \\
(14.635)\end{array}$ & $\begin{array}{c}51.619 * * * \\
(18.916)\end{array}$ & $\begin{array}{l}22.729 \\
(22.992)\end{array}$ & $\begin{array}{l}56.921 * \\
(29.623)\end{array}$ \\
\hline $\begin{array}{l}\text { Democracy in } \\
\text { Neighboring } \\
\text { countries }_{t-5}\end{array}$ & & & & $\begin{array}{l}.015 \\
(.076)\end{array}$ & & & & & $\begin{array}{l}.113 \\
(.120)\end{array}$ \\
\hline $\begin{array}{l}\text { Education } \\
\text { Attainement }_{\mathrm{t}-5}\end{array}$ & & & & & $\begin{array}{c}4.064 * * * \\
(.844)\end{array}$ & & & & $\begin{array}{c}5.169 * * * \\
(1.184)\end{array}$ \\
\hline $\begin{array}{l}\text { Democracy in } \\
\text { trading partners } \mathrm{t}_{\mathrm{t}-5}\end{array}$ & & & & & & $\begin{array}{l}-.031 \\
(.138)\end{array}$ & & & $\begin{array}{l}-.385 \\
(.242)\end{array}$ \\
\hline $\begin{array}{l}\text { Tertiary } \\
\text { enrollment } \mathrm{t}_{-5}\end{array}$ & & & & & & & $\begin{array}{c}6.482^{* * * *} \\
(1.306)\end{array}$ & $\begin{array}{l}7.519^{* *} \\
(3.303)\end{array}$ & $\begin{array}{c}.219 \\
(1.612) \\
-1.858 \\
(2.739)\end{array}$ \\
\hline $\begin{array}{l}\text { Time effects } \\
\text { Country effects }\end{array}$ & Yes & $\begin{array}{l}\text { Yes } \\
\text { Yes }\end{array}$ & $\begin{array}{l}\text { Yes } \\
\text { Yes }\end{array}$ & $\begin{array}{l}\text { Yes } \\
\text { Yes }\end{array}$ & $\begin{array}{l}\text { Yes } \\
\text { Yes }\end{array}$ & $\begin{array}{l}\text { Yes } \\
\text { Yes }\end{array}$ & $\begin{array}{l}\text { Yes } \\
\text { Yes }\end{array}$ & $\begin{array}{l}\text { Yes } \\
\text { Yes }\end{array}$ & $\begin{array}{l}\text { Yes } \\
\text { Yes }\end{array}$ \\
\hline $\begin{array}{l}\text { AR(1) Test } \\
\text { AR(2) Test } \\
\text { Hansen's J test } \\
\text { No. of Instr. } \\
\text { No. of countries } \\
\text { Observations } \\
\text { R-squared }\end{array}$ & $\begin{array}{l}1,107 \\
.76\end{array}$ & $\begin{array}{c}158 \\
1,107 \\
.41\end{array}$ & $\begin{array}{c}.00 \\
.76 \\
.15 \\
139 \\
158 \\
1,107\end{array}$ & $\begin{array}{c}.00 \\
.66 \\
.20 \\
142 \\
157 \\
1,084\end{array}$ & $\begin{array}{l}.00 \\
.73 \\
.32 \\
114 \\
114 \\
781\end{array}$ & $\begin{array}{l}.00 \\
.73 \\
.18 \\
135 \\
150 \\
976\end{array}$ & $\begin{array}{c}.00 \\
.49 \\
.05 \\
110 \\
152 \\
724\end{array}$ & $\begin{array}{c}.00 \\
.51 \\
.27 \\
132 \\
147 \\
861\end{array}$ & $\begin{array}{c}.00 \\
.49 \\
.44 \\
106 \\
106 \\
528\end{array}$ \\
\hline
\end{tabular}

* significant at 10\%; ** significant at 5\%,*** significant at $1 \%$. Robust standard errors clustered by country in parentheses. $\mathrm{AR}(1)$ and $\mathrm{AR}(2)$ are Arellano-Bond test for serial correlations. The sample is an unbalanced panel, comprising data at five year interval between 1955 and 2000. Students abroad, democracy in host countries, and all other control variables are treated as predetermined and are instrumented for using their own first to third lags. 
Table 2b. Dependent variable: polity 2 - Differences

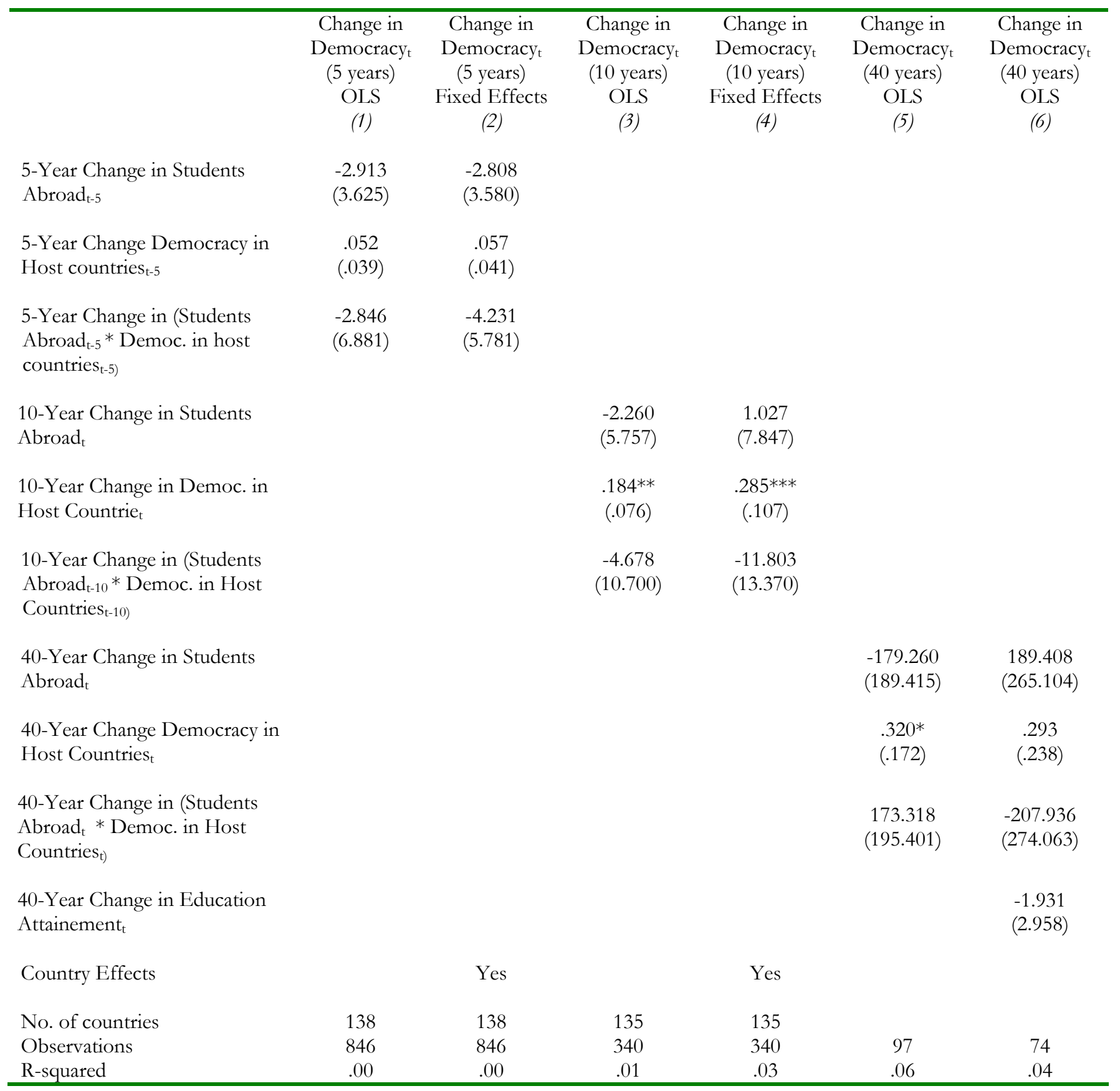

* significant at $10 \%$; ** significant at 5\%, *** significant at $1 \%$. Robust standard errors clustered by country in parentheses. The sample is an unbalanced panel, comprising data between 1955 and 2000. 
Table 3a. Dependent variable: Przeworski et al. democracy index

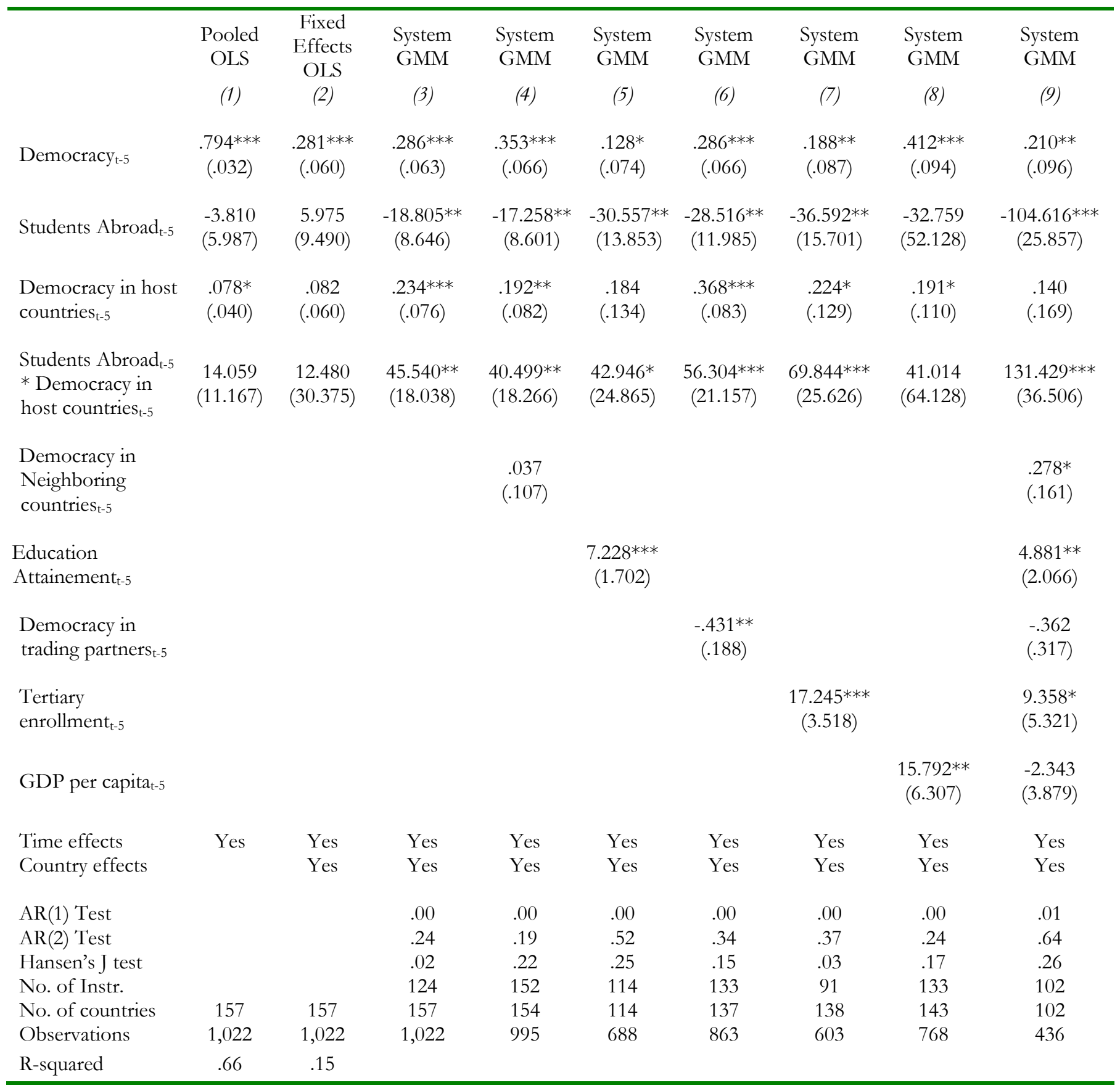

* significant at $10 \%$; ** significant at $5 \%$, *** significant at $1 \%$. Robust standard errors clustered by country in parentheses. AR(1) and $\operatorname{AR}(2)$ are Arellano-Bond test for serial correlations. The sample is an unbalanced panel, comprising data at five year interval between 1955 and 2000. Students abroad, democracy in host countries, and all other control variables are treated as predetermined and are instrumented for using their own first to third lags. 
Table 3b. Dependent variable: Przeworski et al. democracy index - Differences

\begin{tabular}{|c|c|c|c|c|c|c|}
\hline & $\begin{array}{l}\text { Change in } \\
\text { Democracyt } \\
\text { (5 years) } \\
\text { OLS } \\
\text { (1) }\end{array}$ & $\begin{array}{c}\text { Change in } \\
\text { Democracyt } \\
\text { (5 years) } \\
\text { Fixed Effects } \\
\text { (2) }\end{array}$ & $\begin{array}{l}\text { Change in } \\
\text { Democracyt } \\
\text { (10 years) } \\
\text { OLS } \\
\text { (3) }\end{array}$ & $\begin{array}{l}\text { Change in } \\
\text { Democracy } \\
\text { (10 years) } \\
\text { Fixed Effects } \\
\text { (4) }\end{array}$ & $\begin{array}{l}\text { Change in } \\
\text { Democracyt } \\
\text { (40 years) } \\
\text { OLS } \\
\text { (5) }\end{array}$ & $\begin{array}{l}\text { Change in } \\
\text { Democracyt } \\
\text { (40 years) } \\
\text { OLS } \\
\text { (6) }\end{array}$ \\
\hline $\begin{array}{l}\text { 5-Year Change in Students } \\
\text { Abroad }_{t-5}\end{array}$ & $\begin{array}{l}21.296 \\
(21.635)\end{array}$ & $\begin{array}{l}22.998 \\
(22.022)\end{array}$ & & & & \\
\hline $\begin{array}{l}5 \text {-Year Change Democracy in } \\
\text { Host countries } t-5^{\text {to }}\end{array}$ & $\begin{array}{c}.036 \\
(.064)\end{array}$ & $\begin{array}{c}.046 \\
(.069)\end{array}$ & & & & \\
\hline $\begin{array}{l}\text { 5-Year Change in (Students } \\
\text { Abroad }_{\mathrm{t}-5} * \text { Democ. in host } \\
\text { countries }_{\mathrm{t}-5)}\end{array}$ & $\begin{array}{l}-12.258 \\
(14.066)\end{array}$ & $\begin{array}{l}-12.880 \\
(14.442)\end{array}$ & & & & \\
\hline $\begin{array}{l}\text { 10-Year Change in Students } \\
\text { Abroad }_{t}\end{array}$ & & & $\begin{array}{c}3.020 \\
(6.592)\end{array}$ & $\begin{array}{c}12.684 \\
(10.782)\end{array}$ & & \\
\hline $\begin{array}{l}\text { 10-Year Change in Democ. in } \\
\text { Host Countrie }_{t}\end{array}$ & & & $\begin{array}{c}.047 \\
(.112)\end{array}$ & $\begin{array}{l}.209 \\
(.181)\end{array}$ & & \\
\hline $\begin{array}{l}\text { 10-Year Change in (Students } \\
\text { Abroad }_{\mathrm{t}-10} * \text { Democ. in Host } \\
\text { Countries }_{\mathrm{t}-10)}\end{array}$ & & & $\begin{array}{c}11.734 \\
(15.306)\end{array}$ & $\begin{array}{c}5.494 \\
(20.419)\end{array}$ & & \\
\hline $\begin{array}{l}\text { 35-Year Change in Students } \\
\text { Abroad }_{t}\end{array}$ & & & & & $\begin{array}{c}-238.231 * * * \\
(88.980)\end{array}$ & $\begin{array}{l}-120.223 \\
(126.345)\end{array}$ \\
\hline $\begin{array}{l}\text { 35-Year Change Democracy in } \\
\text { Host Countries }_{t}\end{array}$ & & & & & $\begin{array}{l}.466^{* *} \\
(.182)\end{array}$ & $\begin{array}{c}.413 \\
(.282)\end{array}$ \\
\hline $\begin{array}{l}\text { 35-Year Change in (Students } \\
\text { Abroad }_{\mathrm{t}} * \text { Democ. in Host } \\
\left.\text { Countries }_{\mathrm{t}}\right)\end{array}$ & & & & & $\begin{array}{c}251.348^{* * *} \\
(90.284)\end{array}$ & $\begin{array}{c}149.662 \\
(130.489)\end{array}$ \\
\hline $\begin{array}{l}\text { 35-Year Change in Education } \\
\text { Attainement }_{t}\end{array}$ & & & & & & $\begin{array}{l}-3.973 \\
(3.498)\end{array}$ \\
\hline Country Effects & & Yes & & Yes & & \\
\hline No. of countries & 157 & 157 & 146 & 146 & & \\
\hline Observations & 764 & 764 & 361 & 361 & 103 & 78 \\
\hline R-squared & .00 & .00 & .01 & .02 & .08 & .07 \\
\hline
\end{tabular}

* significant at $10 \%$; ** significant at 5\%, *** significant at $1 \%$. Robust standard errors clustered by country in parentheses. The sample is an unbalanced panel, comprising data between 1955 and 2000. 
Table 4. Flows of international students Dependent variable: $\ln$ (bilateral student flow)

\begin{tabular}{|c|c|c|c|c|}
\hline & $\begin{array}{c}\text { Ln (Bilateral } \\
\text { student flows } \\
\text { OLS } \\
\text { (1) }\end{array}$ & $\begin{array}{c}\text { Ln (Bilateral } \\
\left.\text { student flows } s_{t}\right) \\
\text { OLS } \\
\text { (2) }\end{array}$ & $\begin{array}{c}\text { Ln (Bilateral } \\
\left.\text { student flows }{ }_{t}\right) \\
\text { OLS } \\
\text { (3) }\end{array}$ & $\begin{array}{c}\text { Ln (Bilateral } \\
\text { student flows }{ }_{\mathrm{t}} \text { ) } \\
\text { OLS } \\
\text { (4) }\end{array}$ \\
\hline Ln (population origin country f & $\begin{array}{c}.397 * * * \\
(.01)\end{array}$ & $\begin{array}{l}.379 * * * \\
(.010)\end{array}$ & $\begin{array}{l}.360^{* * *} \\
(.010)\end{array}$ & $\begin{array}{l}.284 * * * \\
(.012)\end{array}$ \\
\hline Ln (population receiving country $y_{t}$ & $\begin{array}{l}-.017 \\
(.087)\end{array}$ & $\begin{array}{l}.028 \\
(.078)\end{array}$ & $\begin{array}{l}-.063 \\
(.075)\end{array}$ & $\begin{array}{l}-.261 * * * \\
(.082)\end{array}$ \\
\hline $\begin{array}{l}\text { Ln (total students to receiving country } \\
\text { excluding sending countryt) }\end{array}$ & $\begin{array}{c}.240 * * * \\
(.029)\end{array}$ & $\begin{array}{l}.229 * * * \\
(.026)\end{array}$ & $\begin{array}{c}.247 * * * \\
(.027)\end{array}$ & $\begin{array}{l}.077^{* *} \\
(.032)\end{array}$ \\
\hline Ln (distance) & $\begin{array}{c}-.771 * * * \\
(.024)\end{array}$ & $\begin{array}{c}-.732 * * * \\
(.022)\end{array}$ & $\begin{array}{c}-.723 * * * \\
(.023)\end{array}$ & \\
\hline Contiguity & $\begin{array}{l}.503 * * * \\
(.16)\end{array}$ & $\begin{array}{l}.570^{* * *} \\
(.108)\end{array}$ & $\begin{array}{l}.626^{* * *} \\
(.113)\end{array}$ & \\
\hline Colonial ties & $\begin{array}{c}1.423 * * * \\
(.120)\end{array}$ & $\begin{array}{c}1.429 * * * \\
(.116)\end{array}$ & $\begin{array}{c}1.358^{* * *} \\
(.118)\end{array}$ & \\
\hline Common official language & $\begin{array}{l}.709 * * * \\
(.083)\end{array}$ & $\begin{array}{l}.692 * * * \\
(.079)\end{array}$ & $\begin{array}{l}.701 * * * \\
(.077)\end{array}$ & \\
\hline $\begin{array}{l}\text { Common spoken language } \\
\text { (at least } 9 \text { percent) }\end{array}$ & $\begin{array}{l}.398 * * * \\
(.082)\end{array}$ & $\begin{array}{l}.418^{* * *} \\
(.077)\end{array}$ & $\begin{array}{l}.477 * * * \\
(.075)\end{array}$ & \\
\hline $\begin{array}{l}\text { Democracy in receiving country } \\
\text { (freedom house index) }\end{array}$ & $\begin{array}{l}-.940^{* * *} \\
(.050)\end{array}$ & $\begin{array}{c}-.897 * * * \\
(.046)\end{array}$ & & \\
\hline $\begin{array}{l}\text { Democracy in origin country } \\
\text { (freedom house index) }\end{array}$ & $\begin{array}{l}-.410^{* * *} \\
(.053)\end{array}$ & $\begin{array}{l}-.350^{* * *} \\
(.050)\end{array}$ & & \\
\hline $\begin{array}{l}\text { Absolute difference in democracy in } \\
\text { sending and receiving countries } \\
\text { (freedom house index) }\end{array}$ & $\begin{array}{c}-.309 * * * \\
(.051)\end{array}$ & $\begin{array}{c}-.328^{* * *} \\
(.044)\end{array}$ & & \\
\hline Trend in democracy in sending countries & $\begin{array}{c}-.204 * * * \\
(.035)\end{array}$ & & & \\
\hline Receiving Country Effects & Yes & Yes & Yes & Yes \\
\hline Year Effects & Yes & Yes & Yes & Yes \\
\hline $\begin{array}{l}\text { Number of country origin couples } \\
\text { Observations } \\
\text { R-squared }\end{array}$ & $\begin{array}{c}7,786 \\
119,692 \\
.56\end{array}$ & $\begin{array}{c}9,472 \\
144,273 \\
.54\end{array}$ & $\begin{array}{c}9,843 \\
170,677 \\
.51\end{array}$ & $\begin{array}{l}10,111 \\
173,318 \\
.30\end{array}$ \\
\hline
\end{tabular}

* significant at $10 \%$; ** significant at 5\%,*** significant at 1\%. Robust standard errors clustered by sending and origin country in parentheses. The sample is an unbalanced panel, comprising yearly data between 1951 and 2005. Democracy is measured using the Freedom House index. 
Table 5. Alternative instrumentation strategy

\begin{tabular}{|c|c|c|c|c|c|c|}
\hline & \multicolumn{2}{|c|}{ Freedom House } & \multicolumn{2}{|c|}{ Polity II } & \multicolumn{2}{|c|}{ Przeworski et al. } \\
\hline & (1) & (2) & (3) & (4) & (5) & (6) \\
\hline Democracy ${ }_{t-5}$ & $\begin{array}{c}.481 * * * \\
(.048)\end{array}$ & $\begin{array}{c}.487 * * * \\
(.044)\end{array}$ & $\begin{array}{c}.445^{* * *} \\
(.058)\end{array}$ & $\begin{array}{l}.300 * * * \\
(.062)\end{array}$ & $\begin{array}{l}.279 * * * \\
(.065)\end{array}$ & $\begin{array}{c}.143 * * * \\
(.061)\end{array}$ \\
\hline $\begin{array}{l}\text { Students } \\
\text { Abroad }_{\mathrm{t}-5}\end{array}$ & $\begin{array}{l}-6.699 \\
(25.879)\end{array}$ & $\begin{array}{c}-6.957 \\
(11.474)\end{array}$ & $\begin{array}{c}-3.112 \\
(18.947)\end{array}$ & $\begin{array}{l}-11.144 \\
(14.909)\end{array}$ & $\begin{array}{l}-20.800 \\
(28.838)\end{array}$ & $\begin{array}{c}-14.083^{*} \\
(8.450)\end{array}$ \\
\hline Democracy in host countries $_{t-5}$ & $\begin{array}{c}.208^{* * *} \\
(.063)\end{array}$ & $\begin{array}{l}.272^{* * *} \\
(.091)\end{array}$ & $\begin{array}{l}.367 * * * \\
(.086)\end{array}$ & $\begin{array}{l}.506^{* * *} \\
(.125)\end{array}$ & $\begin{array}{l}.176^{*} \\
(.098)\end{array}$ & $\begin{array}{c}.421 * * * \\
(.140)\end{array}$ \\
\hline $\begin{array}{l}\text { Students } \text { Abroad }_{\mathrm{t}-5} * \text { Democracy in } \\
\text { host countries } \mathrm{t}-5\end{array}$ & $\begin{array}{l}30.493 \\
(28.100)\end{array}$ & $\begin{array}{l}27.286^{* *} \\
(16.359)\end{array}$ & $\begin{array}{c}2.827 \\
(25.545)\end{array}$ & $\begin{array}{l}27.666^{*} \\
(14.669)\end{array}$ & $\begin{array}{l}55.585 \\
(36.512)\end{array}$ & $\begin{array}{c}41.634^{* *} \\
(17.809)\end{array}$ \\
\hline Instrumentation Strategy (see footnote) & A & $\mathrm{B}$ & A & $\mathrm{B}$ & A & B \\
\hline $\begin{array}{l}\text { Time fixed effects } \\
\text { Country fixed effects }\end{array}$ & $\begin{array}{l}\text { Yes } \\
\text { Yes }\end{array}$ & $\begin{array}{l}\text { Yes } \\
\text { Yes }\end{array}$ & $\begin{array}{l}\text { Yes } \\
\text { Yes }\end{array}$ & $\begin{array}{l}\text { Yes } \\
\text { Yes }\end{array}$ & $\begin{array}{l}\text { Yes } \\
\text { Yes }\end{array}$ & $\begin{array}{l}\text { Yes } \\
\text { Yes }\end{array}$ \\
\hline $\begin{array}{l}\operatorname{AR}(1) \text { Test } \\
\operatorname{AR}(2) \text { Test } \\
\text { Hansen's J test }\end{array}$ & $\begin{array}{l}.00 \\
.63 \\
.27\end{array}$ & $\begin{array}{l}.00 \\
.68 \\
.18\end{array}$ & $\begin{array}{l}.00 \\
.70 \\
.24\end{array}$ & $\begin{array}{l}.00 \\
.97 \\
.20\end{array}$ & $\begin{array}{l}.00 \\
.25 \\
.11\end{array}$ & $\begin{array}{l}.00 \\
.51 \\
.03\end{array}$ \\
\hline $\begin{array}{l}\text { No. of Instruments } \\
\text { No. of countries } \\
\text { Observations }\end{array}$ & $\begin{array}{c}175 \\
183 \\
1,379\end{array}$ & $\begin{array}{c}170 \\
183 \\
1,379\end{array}$ & $\begin{array}{c}143 \\
158 \\
1,107\end{array}$ & $\begin{array}{c}141 \\
158 \\
1,107\end{array}$ & $\begin{array}{c}143 \\
157 \\
1,022\end{array}$ & $\begin{array}{c}130 \\
157 \\
1,022\end{array}$ \\
\hline
\end{tabular}

* significant at $10 \%$; $* *$ significant at $5 \%, * * *$ significant at $1 \%$. Robust standard errors clustered by country in parentheses. AR(1) and AR(2) are Arellano-Bond test for serial correlations. The sample is an unbalanced panel, comprising data at five year interval between 1955 and 1985. Students abroad and democracy in host countries are instrumented and the interaction terms are all instrumented. See five for a detailed description on how the instruments were constructed.

Instrumentation strategy $\mathbf{A}$ uses a prediction of bilateral students flows based on a regression which uses only population in host and receiving countries, time dummies, receiving country dummies, and number of foreign student in receiving country excluding the bilateral student flows (Table 4, Column 4; see chapter 5 for details).

Instrumentation strategy B uses 10 year lagged bilateral student flows to construct (see chapter 5 for details). 
Table 6. Alternative Specification of the student variables Dependent variable: Democracy indices

\begin{tabular}{|c|c|c|c|c|c|c|}
\hline & $\begin{array}{c}\text { Freedom } \\
\text { House } \\
\text { GMM } \\
\text { (1) }\end{array}$ & $\begin{array}{c}\text { Freedom } \\
\text { House } \\
\text { GMM } \\
\text { (2) }\end{array}$ & $\begin{array}{l}\text { Polity II } \\
\text { GMM } \\
\text { (3) }\end{array}$ & $\begin{array}{l}\text { Polity II } \\
\text { GMM } \\
\text { (4) }\end{array}$ & $\begin{array}{c}\text { Przeworski } \\
\text { et al. } \\
\text { GMM } \\
(5)\end{array}$ & $\begin{array}{l}\text { Przeworski } \\
\text { et al. } \\
\text { GMM } \\
\text { (6) }\end{array}$ \\
\hline Democracy $_{t-5}$ & $\begin{array}{l}.469 * * * \\
(.051)\end{array}$ & $\begin{array}{l}.403^{* * *} \\
(.054)\end{array}$ & $\begin{array}{c}.371^{* * *} \\
(.078)\end{array}$ & $\begin{array}{c}.304 * * * \\
(.076)\end{array}$ & $\begin{array}{l}.164 * * \\
(.067)\end{array}$ & $\begin{array}{l}.120^{*} \\
(.063)\end{array}$ \\
\hline $\begin{array}{l}\text { Students to democratic } \\
\text { countriest }-5\end{array}$ & $\begin{array}{c}30.438^{* * * *} \\
(6.039)\end{array}$ & $\begin{array}{c}28.074 * * * \\
(6.892)\end{array}$ & $\begin{array}{l}28.924 * \\
(17.176)\end{array}$ & $\begin{array}{l}-25.458 \\
(33.239)\end{array}$ & $\begin{array}{c}40.841 * * * \\
(11.830)\end{array}$ & $\begin{array}{c}56.985^{* *} \\
(24.791)\end{array}$ \\
\hline $\begin{array}{l}\text { Students to NON democratic } \\
\text { countries }_{t-5}\end{array}$ & $\begin{array}{l}-4.701 \\
(7.355)\end{array}$ & $\begin{array}{c}25.842 \\
(26.521)\end{array}$ & $\begin{array}{l}-12.257 \\
(18.199)\end{array}$ & $\begin{array}{c}8.893 \\
(20.466)\end{array}$ & $\begin{array}{l}-48.038^{* * *} \\
(13.484)\end{array}$ & $\begin{array}{c}-6.457 \\
(34.135)\end{array}$ \\
\hline $\begin{array}{l}\text { Time effects } \\
\text { Country effects } \\
\text { Instr. for students }\end{array}$ & $\begin{array}{l}\text { Yes } \\
\text { Yes }\end{array}$ & $\begin{array}{l}\text { Yes } \\
\text { Yes } \\
\text { Yes }\end{array}$ & $\begin{array}{l}\text { Yes } \\
\text { Yes }\end{array}$ & $\begin{array}{l}\text { Yes } \\
\text { Yes } \\
\text { Yes }\end{array}$ & $\begin{array}{l}\text { Yes } \\
\text { Yes }\end{array}$ & $\begin{array}{l}\text { Yes } \\
\text { Yes } \\
\text { Yes }\end{array}$ \\
\hline $\begin{array}{l}\text { AR(1) Test } \\
\text { AR(2) Test } \\
\text { Hansen's J test } \\
\text { No. of Instr. } \\
\text { No. of countries } \\
\text { Observations }\end{array}$ & $\begin{array}{c}.00 \\
.41 \\
.12 \\
117 \\
184 \\
1,385\end{array}$ & $\begin{array}{c}.00 \\
.56 \\
.08 \\
117 \\
184 \\
1,385\end{array}$ & $\begin{array}{c}.00 \\
.74 \\
.66 \\
106 \\
158 \\
1,099\end{array}$ & $\begin{array}{c}.00 \\
.93 \\
.33 \\
106 \\
158 \\
1,099\end{array}$ & $\begin{array}{c}.00 \\
.48 \\
.14 \\
95 \\
157 \\
1,017\end{array}$ & $\begin{array}{c}.00 \\
.56 \\
.20 \\
95 \\
157 \\
1,017\end{array}$ \\
\hline
\end{tabular}

* significant at 10\%; ** significant at 5\%,*** significant at $1 \%$. Robust standard errors clustered by country in parentheses. The sample is an unbalanced panel, comprising data between 1955 and 2005 for specifications 1 and 2 , and between 1955 and 2000 for the other specifications. Students abroad are treated as predetermined and are instrumented for using their own first to third lags. Instrumental variables are described in the text. 
Table 7. Earlier versus later periods (cut-off 1985)

\begin{tabular}{|c|c|c|c|c|c|c|}
\hline & $\begin{array}{c}\text { Freedom } \\
\text { House } \\
\text { Year } \\
\leq 1985 \\
\text { (1) }\end{array}$ & $\begin{array}{c}\text { Freedom } \\
\text { House } \\
\text { Year } \\
>1985 \\
\text { (2) }\end{array}$ & $\begin{array}{l}\text { Polity II } \\
\quad \text { Year } \\
\leq 1985 \\
\text { (3) }\end{array}$ & $\begin{array}{c}\text { Polity II } \\
\text { Year } \\
>1985 \\
\text { (4) }\end{array}$ & $\begin{array}{c}\text { Przeworski } \\
\text { et al. } \\
\text { Year } \\
\leq 1985 \\
\text { (5) }\end{array}$ & $\begin{array}{c}\text { Przeworski } \\
\text { et al. } \\
\text { Year } \\
>1985 \\
\text { (6) }\end{array}$ \\
\hline Democracyt -5 & $\begin{array}{l}.528 * * * \\
(.064)\end{array}$ & $\begin{array}{c}.644 * * * \\
(.043)\end{array}$ & $\begin{array}{c}.401 * * * \\
(.091)\end{array}$ & $\begin{array}{c}.525^{* * * *} \\
(.057)\end{array}$ & $\begin{array}{l}.172 * * \\
(0.084)\end{array}$ & $\begin{array}{c}0.590^{* * *} \\
(.061)\end{array}$ \\
\hline $\begin{array}{l}\text { Students } \\
\text { Abroad }_{t-5}\end{array}$ & $\begin{array}{l}-22.946 * * \\
(9.941)\end{array}$ & $\begin{array}{c}4.739 \\
(17.856)\end{array}$ & $\begin{array}{l}-19.066 \\
(11.958)\end{array}$ & $\begin{array}{l}-34.188 \\
(20.196)\end{array}$ & $\begin{array}{l}-20.656^{*} \\
(11.623)\end{array}$ & $\begin{array}{l}-24.980 \\
(26.032)\end{array}$ \\
\hline $\begin{array}{l}\text { Democracy in host } \\
\text { countriest }-5^{-}\end{array}$ & $\begin{array}{l}.315^{* * *} \\
(.071)\end{array}$ & $\begin{array}{l}.061 \\
(.084)\end{array}$ & $\begin{array}{l}.383 * * * \\
(.086)\end{array}$ & $\begin{array}{l}.222 * * \\
(.105)\end{array}$ & $\begin{array}{l}.389 * * * \\
(0.086)\end{array}$ & $\begin{array}{l}.072 \\
(.119)\end{array}$ \\
\hline $\begin{array}{l}\text { Students } \text { Abroad }_{\mathrm{t}-5} * \\
\text { Democracy in host } \\
\text { countries } \mathrm{t}-5^{\text {a }}\end{array}$ & $\begin{array}{c}52.690^{* * *} \\
(16.305)\end{array}$ & $\begin{array}{c}9.147 \\
(19.340)\end{array}$ & $\begin{array}{l}39.678^{* *} \\
(15.575)\end{array}$ & $\begin{array}{l}44.768^{*} \\
(23.727)\end{array}$ & $\begin{array}{c}60.147 * * * \\
(23.046)\end{array}$ & $\begin{array}{c}39.111 \\
(30.758)\end{array}$ \\
\hline $\begin{array}{l}\text { Time fixed effects } \\
\text { Country fixed } \\
\text { effects }\end{array}$ & $\begin{array}{l}\text { Yes } \\
\text { Yes }\end{array}$ & $\begin{array}{l}\text { Yes } \\
\text { Yes }\end{array}$ & $\begin{array}{l}\text { Yes } \\
\text { Yes }\end{array}$ & $\begin{array}{l}\text { Yes } \\
\text { Yes }\end{array}$ & $\begin{array}{l}\text { Yes } \\
\text { Yes }\end{array}$ & $\begin{array}{l}\text { Yes } \\
\text { Yes }\end{array}$ \\
\hline $\begin{array}{l}\text { AR(1) Test } \\
\text { AR(2) Test } \\
\text { Hansen's J test }\end{array}$ & $\begin{array}{l}0 \\
.97 \\
.01\end{array}$ & $\begin{array}{c}0 \\
.51 \\
0\end{array}$ & $\begin{array}{l}0 \\
.63 \\
.03\end{array}$ & $\begin{array}{c}0 \\
.18 \\
0\end{array}$ & $\begin{array}{c}0 \\
.26 \\
0\end{array}$ & $\begin{array}{l}0 \\
.25 \\
.04\end{array}$ \\
\hline $\begin{array}{l}\text { No. of Instruments } \\
\text { No. of countries } \\
\text { Observations }\end{array}$ & $\begin{array}{c}90 \\
154 \\
707\end{array}$ & $\begin{array}{c}92 \\
182 \\
672\end{array}$ & $\begin{array}{c}90 \\
136 \\
685\end{array}$ & $\begin{array}{c}78 \\
156 \\
422\end{array}$ & $\begin{array}{c}90 \\
147 \\
719\end{array}$ & $\begin{array}{c}65 \\
156 \\
303\end{array}$ \\
\hline
\end{tabular}

* significant at $10 \%$; ** significant at $5 \%, * * *$ significant at $1 \%$. Robust standard errors clustered by country in parentheses. $\mathrm{AR}(1)$ and $\mathrm{AR}(2)$ are Arellano-Bond test for serial correlations. The sample is an unbalanced panel, comprising data at five year interval between 1955 and 1985 for specifications (1), (2), and (3), between 1990 and 2005 for specification (2), and between 1990 and 2000 for specifications (4) and (6). Students abroad and democracy in host countries are considered predetermined and are instrumented for using their own first and second lags. 
Table 8. Small versus Large Countries (cut-off 2 million)

\begin{tabular}{|c|c|c|c|c|c|c|}
\hline & $\begin{array}{l}\text { Freedom } \\
\text { House } \\
\text { Population } \\
<2 \text { mil } \\
\text { (1) }\end{array}$ & $\begin{array}{l}\text { Freedom } \\
\text { House } \\
\text { Population } \\
>2 \text { mil } \\
\text { (2) }\end{array}$ & $\begin{array}{l}\text { Polity II } \\
\text { Population } \\
<2 \text { mil } \\
\text { (3) }\end{array}$ & $\begin{array}{l}\text { Polity II } \\
\text { Population } \\
>2 \text { mil } \\
\text { (4) }\end{array}$ & $\begin{array}{l}\text { Przeworski } \\
\text { et al. } \\
\text { Population } \\
<2 \text { mil } \\
\text { (5) }\end{array}$ & $\begin{array}{l}\text { Przeworski } \\
\text { et al. } \\
\text { Population } \\
>2 \text { mil } \\
\text { (6) }\end{array}$ \\
\hline Democracy $_{\mathrm{t}-5}$ & $\begin{array}{c}.652^{* * *} \\
(.072)\end{array}$ & $\begin{array}{c}.547 * * * \\
(.052)\end{array}$ & $\begin{array}{c}.766^{* * * *} \\
(.085)\end{array}$ & $\begin{array}{c}.439 * * * \\
(.063)\end{array}$ & $\begin{array}{l}.508^{* * *} \\
(.096)\end{array}$ & $\begin{array}{l}.364 * * * \\
(.070)\end{array}$ \\
\hline $\begin{array}{l}\text { Students } \\
\text { Abroad }_{\mathrm{t}-5}\end{array}$ & $\begin{array}{l}-11.936 \\
(10.872)\end{array}$ & $\begin{array}{c}7.463 \\
(16.118)\end{array}$ & $\begin{array}{l}-2.467 \\
(8.472)\end{array}$ & $\begin{array}{l}-20.624 \\
(22.508)\end{array}$ & $\begin{array}{c}-10.512 \\
(6.957)\end{array}$ & $\begin{array}{c}7.542 \\
(19.879)\end{array}$ \\
\hline $\begin{array}{l}\text { Democracy in } \\
\text { host countries } t_{-5}\end{array}$ & $\begin{array}{l}.164 * * \\
(.077)\end{array}$ & $\begin{array}{c}.238^{* * *} \\
(.064)\end{array}$ & $\begin{array}{l}.091 \\
(.066)\end{array}$ & $\begin{array}{c}.365^{* * *} \\
(.074)\end{array}$ & $\begin{array}{l}.196^{*} \\
(.104)\end{array}$ & $\begin{array}{l}.367 * * * \\
(.087)\end{array}$ \\
\hline 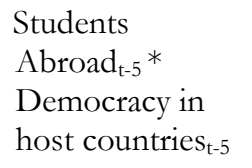 & $\begin{array}{c}30.384 * * \\
(14.633)\end{array}$ & $\begin{array}{c}-4.904 \\
(26.627)\end{array}$ & $\begin{array}{c}11.826 \\
(10.079)\end{array}$ & $\begin{array}{c}29.739 \\
(40.415)\end{array}$ & $\begin{array}{c}50.415^{* * *} \\
(11.101)\end{array}$ & $\begin{array}{l}-36.169 \\
(54.140)\end{array}$ \\
\hline $\begin{array}{l}\text { Time fixed } \\
\text { effects }\end{array}$ & Yes & Yes & Yes & Yes & Yes & Yes \\
\hline $\begin{array}{l}\text { Country fixed } \\
\text { effects }\end{array}$ & Yes & Yes & Yes & Yes & Yes & Yes \\
\hline AR(1) Test & .00 & .00 & .01 & .00 & .07 & .00 \\
\hline AR(2) Test & .52 & .78 & .80 & .67 & .04 & .18 \\
\hline Hansen's J test & 1.00 & .38 & 1.00 & .53 & 1.00 & .35 \\
\hline $\begin{array}{l}\text { No. of } \\
\text { Instruments }\end{array}$ & 140 & 155 & 137 & 141 & 117 & 128 \\
\hline $\begin{array}{l}\text { No. of } \\
\text { countries }\end{array}$ & 60 & 180 & 39 & 138 & 55 & 121 \\
\hline Observations & 266 & 1,113 & 160 & 947 & 204 & 818 \\
\hline
\end{tabular}

* significant at $10 \%$; $* *$ significant at $5 \%$, *** significant at $1 \%$. Robust standard errors clustered by country in parentheses. AR(1) and AR(2) are Arellano-Bond test for serial correlations. The sample is an unbalanced panel, comprising data at five year interval between 1955 and 2005. Students abroad and democracy in host countries are considered predetermined and are instrumented for using their own first and second lags and their differences. 
Table 9. Stay Rates of Foreign Doctorate Recipients in US

\begin{tabular}{lccc}
\hline Country of origin & $\begin{array}{c}\text { Foreign } \\
\text { Doctorate } \\
\text { Recipients in } \\
1994 / 95\end{array}$ & $\begin{array}{c}\text { Estimated stay } \\
\text { rates in 1999 }\end{array}$ & $\begin{array}{c}\text { Percentage of non-US } \\
\text { Doctorate recipients } \\
\text { intending to stay in US } \\
\text { (1average 1999-2001) }\end{array}$ \\
\hline Taiwan & $(1)$ & $(2)$ & $(3)$ \\
India & 2,268 & 42.4 & 57.3 \\
South Korea & 1,995 & 87.5 & 88.2 \\
China & 1,943 & 15.1 & 59.0 \\
Brazil & 1,649 & 91.1 & 90.8 \\
Mexico & 255 & 21.1 & 36.0 \\
Chile & 223 & 30.8 & 39.8 \\
Turkey & 57 & 26.1 & 54.5 \\
Indonesia & 252 & 43.7 & 55.3 \\
Italy & 119 & 16.4 & $\ldots$ \\
Greece & 106 & 37.1 & 62.0 \\
Spain & 276 & 49.1 & 70.0 \\
Canada & 87 & 34.0 & 62.0 \\
Argentina & 430 & 55.1 & 64.2 \\
Colombia & 67 & 44.7 & 62.5 \\
& 66 & 28.5 & 57.5 \\
Total, all countries & & & $\mathbf{6 9 . 1}$ \\
\hline Total, all countries & $\mathbf{1 4 , 1 8 9}$ & $\mathbf{5 3 . 5}$ & $\mathbf{5 9 . 5}$ \\
excluding China and India & $\mathbf{1 0 , 5 4 5}$ & $\mathbf{3 8 . 8}$ & \\
\hline & & & \\
\hline
\end{tabular}

Source: Finn (2001), Table 32 from the Doctorate recipients from US universities (2005), and author's elaboration. 
Table 10. Summary Statistics

\begin{tabular}{|c|c|c|c|c|c|}
\hline & Obs. & Mean & Std. Dev. & Min. & Max. \\
\hline $\begin{array}{l}\text { Foreign students as a share } \\
\text { of population (X 1000) }\end{array}$ & 1,379 & 1.031 & 2.151 & 0.001 & 20.130 \\
\hline Freedom House Index & 1,379 & .521 & .376 & 0 & 1 \\
\hline $\begin{array}{l}\text { Freedom House Index in } \\
\text { host countries }\end{array}$ & 1,379 & .838 & .201 & .001 & 1 \\
\hline $\begin{array}{l}\text { Freedom House Index in } \\
\text { trading partners }\end{array}$ & 1,166 & .922 & .089 & .324 & 1 \\
\hline $\begin{array}{l}\text { Freedom House Index in } \\
\text { neighboring countries }\end{array}$ & 1,358 & .759 & .160 & .001 & 1 \\
\hline Polity II Index & 1,107 & .499 & .380 & 0 & 1 \\
\hline $\begin{array}{l}\text { Polity II Index in host } \\
\text { countries }\end{array}$ & 1,107 & .826 & .197 & .150 & 1 \\
\hline $\begin{array}{l}\text { Polity II Index in trading } \\
\text { partners }\end{array}$ & 976 & .921 & .092 & .150 & 1 \\
\hline $\begin{array}{l}\text { Polity II in neighboring } \\
\text { countries }\end{array}$ & 1,084 & .774 & .157 & .150 & 1 \\
\hline Przeworski Index & 1,022 & .371 & .483 & 0 & 1 \\
\hline $\begin{array}{l}\text { Przeworski Index in host } \\
\text { countries }\end{array}$ & 1,022 & .81 & .243 & .003 & 1 \\
\hline $\begin{array}{l}\text { Przeworski Index in trading } \\
\text { partners }\end{array}$ & 863 & .926 & .101 & .058 & 1 \\
\hline $\begin{array}{l}\text { Przeworski Index in } \\
\text { neighboring countries }\end{array}$ & 995 & .752 & .190 & .045 & 1 \\
\hline $\begin{array}{l}\text { Education attainment }(\mathrm{X} \\
100)\end{array}$ & 899 & 5.055 & 2.837 & .120 & 12.050 \\
\hline Enrollment (X 100) & 877 & 1.502 & 1.651 & .002 & 9.312 \\
\hline GDP per capita (X1000) & 1,093 & 5,056 & 7,541 & .045 & 46,473 \\
\hline
\end{tabular}

The statistics refer only to the sample used in the regressions. 
Table 11. Education of world leaders in $\mathbf{1 9 9 0}$

\begin{tabular}{|c|c|c|c|c|c|c|}
\hline Country & Last name & First name & Primary & secondary & tertiary & other \\
\hline Angola & Dos Santos & Jose Eduardo & . & . & Russia & . \\
\hline Argentina & Menem & Carlos & Argentina & Argentina & Argentina & . \\
\hline Australia & Hawke & $\begin{array}{l}\text { Robert James } \\
\text { Lee }\end{array}$ & Australia & Australia & Australia & UK \\
\hline Austria & Vranitzky & Franz & Austria & Austria & Austria & \\
\hline Bangladesh & Ershad & $\begin{array}{l}\text { Hossain } \\
\text { Mohammad }\end{array}$ & Bangladesh & Bangladesh & Bangladesh & India \\
\hline Barbados & Sandiford & Lloyd Erskine & . & . & Jamaica & UK \\
\hline Belgium & Martens & Wilfried & . & . & Belgium & . \\
\hline Benin & Kerekou & Mathieu & & & France & \\
\hline Bolivia & Paz (Zamora) & Jaime & Bolivia & Bolivia & Chile & . \\
\hline Brazil & Sarnay & Jose & Brazil & Brazil & Brazil & . \\
\hline Cameroon & Biya & Paul & . & . & France & . \\
\hline Canada & Mulroney & Martin Brian & Canada & Canada & Canada & . \\
\hline Chad & Habre & Hissene & Chad & Chad & France & . \\
\hline Chile & $\begin{array}{l}\text { Pinochet } \\
\text { (Ugarte) }\end{array}$ & Augusto & Chile & Chile & . & Chile \\
\hline China & Xiaoping & Deng & China & China & France & Russia \\
\hline Colombia & Gaviria(Trujillo) & Cesar & . & . & Colombia & . \\
\hline $\begin{array}{l}\text { Congo, } \\
\text { Dem. Rep. }\end{array}$ & Seko & $\begin{array}{l}\text { Mobutu Sese } \\
\text { (Joseph) }\end{array}$ & $\begin{array}{l}\text { Congo, } \\
\text { Dem. Rep. }\end{array}$ & $\begin{array}{l}\text { Congo, } \\
\text { Dem. Rep. }\end{array}$ & . & Belgium \\
\hline $\begin{array}{l}\text { Congo, } \\
\text { Republic of }\end{array}$ & Sassou-Nguesso & Denis & . & . & . & $\begin{array}{l}\text { Algeria } \\
\text { France }\end{array}$ \\
\hline Costa Rica & Sanchez & $\begin{array}{l}\text { Oscar Rafael } \\
\text { de Jesus Arias }\end{array}$ & Costa Rica & Costa Rica & US & Costa Rica \\
\hline $\begin{array}{l}\text { Cote } \\
\text { d'Ivoire }\end{array}$ & $\begin{array}{l}\text { Houphouet- } \\
\text { Boigny }\end{array}$ & Felix & $\begin{array}{l}\text { Cote } \\
\text { d'Ivoire }\end{array}$ & $\begin{array}{l}\text { Cote } \\
\text { d'Ivoire }\end{array}$ & Senegal & . \\
\hline Denmark & Schluter & $\begin{array}{l}\text { Poul } \\
\text { Holmskov }\end{array}$ & . & . & Denmark & Denmark \\
\hline Dominica & Charles & Mary Eugenia & Dominica & Dominica & Canada & $\begin{array}{l}\text { UK } \\
\text { Grenada }\end{array}$ \\
\hline Dominican & Balaguer y & Joaquin & Dominican & Dominican & Dominican & France \\
\hline Republic & Ricardo & Amparo & Republic & Republic & Republic & \\
\hline Ecuador & Borja (Cevallos) & Rodrigo & Ecuador & Ecuador & Ecuador & Ecuador \\
\hline Egypt & Mubarak & Hosni & Egypt & Egypt & Egypt & \\
\hline El Salvador & Burkard & $\begin{array}{l}\text { Alfredo Felix } \\
\text { Cristiani }\end{array}$ & El Salvador & El Salvador & US & \\
\hline Equatorial & Obiang & Teodoro & Equatorial & Equatorial & Spain & \\
\hline Guinea & Nguema & & Guinea & Guinea & & \\
\hline Ethiopia & Haile Mariam & Mengistu & Ethiopia & Ethiopia & Ethiopia & \\
\hline
\end{tabular}

(Continues)

Source: Author's research. The list of leaders is from the list of world leaders from Jones and Olken (2005). The table includes leaders who were in power in 1990. The information was collected by checking biography of each leader. If no information was available a missing value is indicated. 
Table 11. (Continuation) Education of world leaders in 1990

\begin{tabular}{|c|c|c|c|c|c|c|}
\hline Country & Last name & First name & primary & Secondary & tertiary & other \\
\hline Fiji & Mara & Kamisese & . & . & New Zealand & UK \\
\hline Finland & Koivisto & Mauno Henrik & Finland & Finland & Finland & Finland \\
\hline France & Mitterrand & Francois & France & France & France & . \\
\hline Gabon & Bongo & Omar & Congo, Rep. & Congo, Rep. & . & Chad \\
\hline Gambia, The & Jawara & Sir Dawda & . & . & UK & . \\
\hline Ghana & Rawlings & Jerry & Ghana & Ghana & . & Ghana \\
\hline Greece & Mitsotakis & $\begin{array}{l}\text { Konstantinos } \\
\text { Kiriakou }\end{array}$ & . & . & Greece & . \\
\hline Guatemala & Arevalo & $\begin{array}{l}\text { Marco Vinicio } \\
\text { Cerezo }\end{array}$ & Guatemala & Guatemala & Guatemala & . \\
\hline Guinea & Conte & Lansana & & $\begin{array}{l}\text { Cote } \\
\text { d'Ivoire }\end{array}$ & & \\
\hline Honduras & Romero & . & . & . & US & \\
\hline Hungary & Antall & Jozsef & Hungary & Hungary & Hungary & \\
\hline Iceland & Hermannsson & Steingrimur & Iceland & Iceland & US & US \\
\hline India & Shekhar & Chandra & . & . & . & India \\
\hline Indonesia & Suharto & & . & . & Indonesia & . \\
\hline Iran & Khamenei & $\begin{array}{l}\text { Sayyed } \\
\text { Mohammad } \\
\text { Ali Hoseyn }\end{array}$ & Iran & Iran & Iran & \\
\hline Ireland & Haughey & Charles James & Ireland & Ireland & Ireland & . \\
\hline Israel & Shamir & Yitzhak & . & Poland & Palestine & \\
\hline Italy & Andreotti & Giulio & . & . & Italy & \\
\hline Jamaica & Manley & $\begin{array}{l}\text { Michael } \\
\text { Norman }\end{array}$ & . & . & UK & \\
\hline Japan & Kaifu & Toshiki & . & . & Japan & \\
\hline Jordan & al-Hashimi & $\begin{array}{l}\text { Hussein ibn } \\
\text { Talal }\end{array}$ & . & UK & UK & \\
\hline Kenya & Moi & Daniel Arap & . & Kenya & Kenya & \\
\hline $\begin{array}{l}\text { Korea, } \\
\text { Republic of }\end{array}$ & Roh & Tae Woo & . & $\begin{array}{l}\text { Korea, } \\
\text { Republic Of }\end{array}$ & $\begin{array}{l}\text { Korea, } \\
\text { Republic Of }\end{array}$ & \\
\hline Lesotho & Lekhanya & Justin & . & . & . & \\
\hline Liberia & Doe & Samuel K. & . & . & . & \\
\hline Liberia & Sawyer & Amos & . & . & . & US \\
\hline Luxembourg & Santer & Jacques & . & . & France & France \\
\hline Madagascar & Ratsiraka & Didier & . & Madagascar & France & \\
\hline Malawi & Banda & Hastings $\mathrm{K}$. & . & US & US & UK \\
\hline Malaysia & Mohamad & $\begin{array}{l}\text { Datuk Ser } \\
\text { Mahathir Bin }\end{array}$ & . & . & Malaysia & Singapore \\
\hline Mali & Traore & Moussa & . & Mali & France & . \\
\hline
\end{tabular}


Table 11. (Continuation) Education of world leaders in 1990

\begin{tabular}{|c|c|c|c|c|c|c|}
\hline Mauritania & Taya & $\begin{array}{l}\text { Maaouya Ould } \\
\text { Sid'ahmed }\end{array}$ & Mauritania & Mauritania & Mauritania & \\
\hline Mauritius & Jugnauth & Aneerood & & . & UK & . \\
\hline Mexico & de Gortari & Carlos Salinas & . & . & Mexico & US \\
\hline Morocco & Mohammed & $\begin{array}{l}\text { Mawlay al-Hasan II } \\
\text { ibn }\end{array}$ & . & . & Morocco & France \\
\hline Mozambique & Chissano & Joaquim & Mozambique & Mozambique & France & Portugal \\
\hline Namibia & Nujoma & Sam & Namibia & Namibia & & \\
\hline Nepal & Birendra & $\begin{array}{l}\text { Mohan Shumshere } \\
\text { J.B. }\end{array}$ & . & UK & US & Japan \\
\hline Netherlands & Lubbers & $\begin{array}{l}\text { Rudolphus Frans } \\
\text { Marie (Ruud) }\end{array}$ & . & . & Netherlands & . \\
\hline New Zealand & Palmer & $\begin{array}{l}\text { Geoffrey Winston } \\
\text { Russel }\end{array}$ & . & New Zealand & New Zealand & US \\
\hline Nicaragua & Saavedra & Jose Daniel Ortega & Nicaragua & Nicaragua & Nicaragua & . \\
\hline Niger & Seibou & Ali & . & Senegal & Niger & . \\
\hline Nigeria & Babangida & Ibrahim & Nigeria & Nigeria & UK & . \\
\hline Norway & Brundtland & Gro Harlem & . & . & Norway & US \\
\hline Pakistan & Sharif & Nawaz & . & Pakistan & Pakistan & Pakistan \\
\hline Pakistan & Bhutto & Benazir & Pakistan & Pakistan & US & UK \\
\hline Panama & Galimany & $\begin{array}{l}\text { Guillermo David } \\
\text { Endara }\end{array}$ & . & . & Panama & US \\
\hline $\begin{array}{l}\text { Papua New } \\
\text { Guinea }\end{array}$ & Namaliu & Rabbie & . & . & $\begin{array}{l}\text { Papua New } \\
\text { Guinea }\end{array}$ & Canada \\
\hline Paraguay & $\begin{array}{l}\text { Rodriguez } \\
\text { (Pedotti) }\end{array}$ & Andres & . & . & 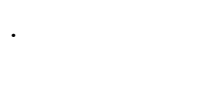 & . \\
\hline Peru & Garcia (Perez) & Alan & Peru & Peru & Peru & Spain \\
\hline Philippines & Aquino & Corazon & US & US & US & Philippines \\
\hline Poland & Walesa & Lech & Poland & . & . & . \\
\hline Portugal & Silva & Anibal Cavaco & . & . & US & UK \\
\hline Romania & Iliescu & Ion & Romania & Romania & Russia & . \\
\hline Rwanda & Habyarimana & Juvenal & $\cdot$ & . & Zaire & Zaire \\
\hline $\begin{array}{l}\text { Sao Tome } \\
\text { and Principe }\end{array}$ & Costa & Manuel Pinto Da & . & . & . & . \\
\hline Senegal & Diouf & Abdul & . & . & . & . \\
\hline Seychelles & Rene & France Albert & . & . & UK & UK \\
\hline Sierra Leone & Momoh & Joseph Saidu & . & . & . & $\begin{array}{l}\text { Ghana, } \\
\text { Nigeria,UK }\end{array}$ \\
\hline
\end{tabular}


Table 11. (Continuation)Education of world leaders in 1990

\begin{tabular}{|c|c|c|c|c|c|c|}
\hline Singapore & Lee & Kuan Yew & Singapore & Singapore & Singapore & UK \\
\hline Singapore & Goh & Chok Tong & . & . & Singapore & US \\
\hline Somalia & Barre & $\begin{array}{l}\text { Mohammed } \\
\text { Siad }\end{array}$ & & & & Italy \\
\hline South Africa & de Klerk & F.W. & . & . & South Africa & . \\
\hline Spain & Marquez & $\begin{array}{l}\text { Felipe } \\
\text { Gonzales }\end{array}$ & . & . & Spain & Spain \\
\hline Sri Lanka & Premadasa & Ranasinghe & . & . & Sri Lanka & . \\
\hline $\begin{array}{l}\text { St. Kitts \& } \\
\text { Nevis }\end{array}$ & Simmonds & Kennedy & $\begin{array}{l}\text { St. Kitts \& } \\
\text { Nevis }\end{array}$ & $\begin{array}{l}\text { St. Kitts \& } \\
\text { Nevis }\end{array}$ & Jamaica & Bahamas \\
\hline St. Lucia & Compton & John & . & . & . & UK \\
\hline $\begin{array}{l}\text { St.Vincent \& } \\
\text { Grenadines }\end{array}$ & Mitchell & $\begin{array}{l}\text { James Fitz- } \\
\text { Allen }\end{array}$ & . & . & $\begin{array}{l}\text { Trinidad } \\
\text { \&Tobago }\end{array}$ & Canada \\
\hline Sudan & Al-Bashir & Omar & . & . & . & Egypt \\
\hline Sweden & Carlsson & Ingvar Gosta & Sweden & Sweden & US & t \\
\hline Switzerland & Koller & Arnold & . & . & . & . \\
\hline Syria & al-Assad & $\begin{array}{l}\text { Abu Sulayman } \\
\text { Hafiz }\end{array}$ & Syria & Syria & & Syria \\
\hline Taiwan & Teng-Hui & Lee & Taiwan & Taiwan & Japan & Taiwan \\
\hline Tanzania & Mwinyi & Ali Hassan & Tanzania & Tanzania & Tanzania & UK \\
\hline Thailand & Choonhavan & Chatichai & Thailand & Thailand & Thailand & US \\
\hline Togo & Eyadema & Gnassingbe & Togo & Togo & . & . \\
\hline $\begin{array}{l}\text { Trinidad \& } \\
\text { Tobago }\end{array}$ & Robinson & $\begin{array}{l}\text { Arthur } \\
\text { Napoleon }\end{array}$ & $\begin{array}{l}\text { Trinidad \& } \\
\text { Tobago }\end{array}$ & $\begin{array}{l}\text { Trinidad \& } \\
\text { Tobago }\end{array}$ & UK & UK \\
\hline Tunisia & Ali & $\begin{array}{l}\text { Zine El } \\
\text { Abidine Ben }\end{array}$ & . & . & France & US \\
\hline Turkey & Ozal & Turgut & Turkey & Turkey & Turkey & US \\
\hline USA & Bush & George H. & US & US & USA & . \\
\hline Uganda & Museveni & Yoweri & Uganda & Uganda & Tanzania & . \\
\hline $\begin{array}{l}\text { United } \\
\text { Kingdom }\end{array}$ & Major & John Roy & UK & UK & . & . \\
\hline $\begin{array}{l}\text { United } \\
\text { Kingdom }\end{array}$ & Thatcher & Margaret Hilda & UK & UK & UK & . \\
\hline Uruguay & Lacalle & Luis & . & . & Uruguay & . \\
\hline Uruguay & $\begin{array}{l}\text { Sanguinetti } \\
\text { (Cairolo) }\end{array}$ & Julio & . & . & Uruguay & . \\
\hline Venezuela & Perez & Carlos Andres & . & Venezuela & Venezuela & . \\
\hline Yemen & al-Hashidi & $\begin{array}{l}\text { Ali 'Abd Allah } \\
\text { Saleh }\end{array}$ & Yemen & Yemen & Yemen & . \\
\hline Zimbabwe & Mugabe & Robert & . & . & South Africa & UK \\
\hline
\end{tabular}




\section{References}

Acemoglu, Daron, and James A. Robinson, 2005, Economic Origin of Dictatorship and Democracy, (Cambridge, Massachusetts: University Press).

Acemoglu, Daron, Simon Johnson, James A. Robinson, and Pierre Yared, 2005a, "From Education to Democracy," American Economic Review Papers and Proceedings, (May).

—_, 2005b, "Income and Democracy,” NBER Working Paper No. 11205, (Cambridge, Massachusetts: National Bureau of Economic Research).

Akerlof, George A and Rachel E. Kranton, 2005, "Identity and the Economics of Organizations," Journal of Economic Perspectives, Vol. 19, pp. 9-32.

Armstrong, Karen, 2000, The Battle for God: Fundamentalism in Judaism, Christianity and Islam (New York: Harper Collins, 2000).

Arellano, Manuel, and Stephen R. Bond, 1991, "Some Specification Tests for Panel Data: Monte Carlo Evidence and an Application to Employment Equations," Review of Economic Studies, Vol. 58, pp. 277-98.

Aslambeigui, Hahid, and Verónica Montecinos, 1998, "Foreign Students in U.S. Doctoral Programs," Journal of Economic Perspectives, Vol. 12 No. 3, (Summer 1998), pp. 171-82.

Atkinson, Carol, 2006, "Constructivist Implications of Material Power: Military Engagement and the Socialization of States, 1972-2000,” International Studies Quarterly. Vol. 50. No. 3 (September 2006), pp. 509-537.

Baker, Joe G., and Michael G. Finn, 2003, "Stay Rates of Foreign National Doctoral Students in U.S. Economics Programs," (March), Mimeo, available at SSRN's website: http://ssrn.com/abstract $=398640$ 
Barnett George A., and Reggie Yingli Wu, 1995, “The International Student Exchange Network: 1970 and 1989," Higher Education, Vol. 30, pp. 353-68.

Barro, Robert J., 1997, “The Determinants of Democracy,” Journal of Political Economy, No. 107, S158-S183.

Barro, Robert J., and Jong-Wha Lee, 2000, “International Data on Educational Attainment: Updates and Implications," CID Working Paper No. 42.

Blundell, Richard, and Stephen R. Bond, 1998, "Initial Conditions and Moment Restrictions in Dynamic Panel Data Models," Journal of Econometrics, No. 87, pp. 115-43.

Boix, Charles, and Sebastián Rosato, 2001, “A Complete Data Set of Political Regimes, 18001999," Unpublished manuscript: Department of Political Science, (Chicago: University of Chicago).

Bollag, Burton, 1990, "Fall of Communist Governments Has Cut Enrollment of Third-World Students in Eastern-Block Universities," The Chronicle of Higher Education, Vol. 37, No. 1.

Bollen, Kenneth A., 1990, "Political Democracy: Conceptual and Measurement Traps," Studies in Comparative International Development, No. 25, pp. 7-24.

__ 2001, “Cross-National Indicators of Liberal Democracy, 1950-90,” [Computer file], $2^{\text {nd }}$ CPSR version, (Chapel Hill, North Carolina: University of North Carolina [producer], 1998). Inter-University Consortium for Political and Social Research.

Bond, Stephen R., 2002, "Dynamic Panel Data Models: a Guide to Microdata Methods and Practice," 2002, Portuguese Economic Journal, Vol. 1, (January), pp. 141-62. 
Borjas , George J., 2000, "Foreign-Born Teaching Assistants and the Academic Performance of Undergraduates," American Economic Review, (May), pp. 355-59.

__, 2000a, "Center for Immigration Studies Backgrounder," (June).

— , 2002b, "Rethinking Foreign Students," National Review, (June), 2nd issue.

—_, 2005, "Do Foreign Students Crowd Out Native Students from Graduate Programs," in Science and the University, edited by Ronald G. Ehrenberg and Paula E. Stephan, forthcoming: (Wisconsin: University of Wisconsin Press).

Bratsberg, Bernt, 1995, “The incidence of No-return Among Foreign Students in the United States," Economics of Education Review, Vol. 14 (4), pp. 373-84.

Bu, Liping, 2003, Making the World like Us. Education, Cultural Expansion, and the American Century. (Westport, Connecticut: Praeger Publishers).

Carrington, William J., and Enrica Detragiache, 1998, “How Big Is the Brain Drain?” IMF Working Paper 98/102 (Washington: International Monetary Fund).

Doctorate Recipients from United States Universities: Summary Report 2004, Survey of Earned Doctorates, (University of Chicago: NORC National Organization for Research and Computing) from website: http://www.norc.uchicago.edu/issues/sed-2004.pdf)

Castelló-Climent, Amparo, 2006, "Distribution of Education and Democracy,” Manuscript: (Valencia, Spain: University of Valencia Institute of International Economics), June.

Desruisseaux, Paul, 2000, “As Exchanges Lose a Political Rationale, their Role is Debated," The Chronicle of Higher Education, Vol.46, Issue 23. 
Dreher, Axel, Michael Lamla, Sarah Rupprecht, and Frank Somogyi, 2006, "The impact of political leaders' profession and education on reforms," mimeo.

Finn, Michael G., 2001, “Stay rates of Foreign Doctorate Recipients from U.S. Universities," Mimeo: Oak Ridge Institute for Science and Education.

Freedom House, 2004, Freedom in the World, website "http://www.freedomhouse.org/".

Gardner, John W.,1952, “The Foreign Student in America,” Foreign Affairs, Vol. 30 Issue 4, pp. 637-50.

Glaeser, Edward L., Giacomo A.M. Ponzetto, and Andrei Shleifer, 2006, "Why does Democracy Need Education?” NBER Working Paper No. 12128, (Cambridge, Massachusetts: National Bureau of Economic Research).

Glaeser, Edward L., Rafael La Porta, Florencio Lopez-de-Silanes, and Andrei Shleifer, 2004, “Do Institutions Cause Growth?” Journal of Economic Growth, No. 9, 271-303.

Glaser, William A., 1979, The Brain Drain: Emigration and Return, (New York: Pergamon Publishers).

Hanushek, A. Erik, and Dennis K. Kimko, 2000, "Schooling, Labor Force Quality, and the Growth of Nations," American Economic Review, Vol. 90 No. 5. pp. 1184-1208.

Jones, Benjamin F., and Benjamin A. Olken, 2005, "Do Leaders Matter? National Leadership and Growth since World War II," Quarterly Journal of Economics, Vol. 120(3) pp. 835-64.

Kim, J., 1998, "Economic Analysis of Foreign Education and Students Abroad," Journal of Development Economics, Vol. 56 Issue 2, pp. 337-65. 
Lipset, Seymour M., 1959, “Some Social Requisites of Democracy: Economic Development and Economic Legitimacy," American Political Science Review, Vol. 53, pp. 69-105.

Lipset, Seymour M., 1967, "Values, Education, and Entrepreneurship” in Seymour M. Lipset and Aldo Solari (eds.) Elites in Latin America (New York: Cambridge University Press)

Li, Quan, and Rafael Reuveny, 2003. "Economic Globalization and Democracy: an Empirical Analysis," British Journal of Political Science, Vol. 33 pp. 29-54.

López-Córdova J. Ernesto, and Christopher Meissner, 2005, “The Globalization of Trade and Democracy, 1870-2000,” NBER Working Paper 11117, (Cambridge, Massachusetts: National Bureau of Economic Research).

Malan, Stephanus, 2001, "Contributing to the African Renaissance Vision: the Role of South African Higher Education Institutions," Development Southern Africa, Vol. 18 No. 4, pp. 513-23.

Markoff, John, and Verónica Montecino, 1993, “The Ubiquitous Rise of Economists," Journal of Public Policy, Vol. 13 Issue 1. pp. 36-68.

Milligan, Kevin, Enrico Moretti, and Philip Oreopoulos, 2004, "Does Education Improve Citizenship? Evidence from the United States and the United Kingdom," Journal of Public Economics, Vol. 88. pp. 1667-95.

North, Douglass C., 1981, Structure and Change in Economic History, (New York: Norton \& Co.)

Nye, Joseph S. Jr., 2004, Soft Power. New York: Public Affairs.

Papaioannou, Elias, and Gregorios Siourounis, 2005, "Economic and Social Factors Driving the Third Wave of Democratization,” mimeo, (London: London Business School). 
Parsons, Talcott, 1960, Structure and Process in Modern Society, (New York: The Free Press)

Przeworski, Adam, Michael Alvarez, José A. Cheibub, and Fernando Limongi, 2000, Democracy and Development: Political Institutions and Material Well-being in the World, 1950-1990, (New York: Cambridge University Press).

Richmond, Yale, 2003, Cultural Exchange and the Cold War: Raising the Iron Curtain. (University Park, Pennsylvania: Pennsylvania State University Press).

Rigobón, Roberto, and Dani Rodrik, 2005, "Rule of Law, Democracy, Openness, and Income: Estimating the Interrelationships," The Economics of Transition, Vol. 13 No. 3, pp. 533-64.

Rosenzweig, Mark R, 2007, “Global Differences and International Student Flows” Brookings Trade Forum, forthcoming.

Sakellaris, Plutarchos, and Antonio Spilimbergo, 2000, "Business Cycle and Human Capital Investment: Country Evidence on University Student Flow to the U.S.," Carnegie-Rochester Conference Series on Public Policy, Issue 52 No. 1, (June), pp 221-56.

Valdés, Juan Gabriel, 1995, Pinochet's Economists, The Chicago School in Chile, (Cambridge, Massachusetts: Cambridge University Press).

Selltiz, Claire, June R. Christ, Joal Havel, and Stuart W. Cook, 1963, Attitudes and Social Relations of Foreign Students in the United States. (Minneapolis, Minnesota: Minnesota University Press).

Wooldridge, Jeffrey M., 2002, Econometric Analysis of Cross Section and Panel Data, (Cambridge, Massachusetts: The MIT Press).

Ye, Weili, 2001, Seeking Modernity in China's Name Chinese Students in the United States, 1900-1927, (Stanford, California: Stanford University Press). 